\title{
Alcohol and Head and Neck Cancer: Updates on the Role of Oxidative Stress, Genetic, Epigenetics, Oral Microbiota, Antioxidants, and Alkylating Agents
}

Giampiero Ferraguti ${ }^{1}$, Sergio Terracina ${ }^{1} \mathbb{D}$, Carla Petrella ${ }^{2} \mathbb{D}$, Antonio Greco ${ }^{3}$, Antonio Minni ${ }^{3}$, Marco Lucarelli ${ }^{1}$ (D) Enzo Agostinelli ${ }^{3}$ (D) , Massimo Ralli ${ }^{3}\left(\mathbb{D}\right.$, Marco de Vincentiis $^{3}$, Giammarco Raponi ${ }^{4}$, Antonella Polimeni ${ }^{5}\left(\mathbb{D}\right.$, Mauro Ceccanti ${ }^{6,7}$, Brunella Caronti ${ }^{8}$, Maria Grazia Di Certo ${ }^{2}$, Christian Barbato ${ }^{2} \mathbb{D}_{\text {, }}$ Alessandro Mattia ${ }^{9}$ (D), Luigi Tarani ${ }^{10}(\mathbb{D})$ and Marco Fiore ${ }^{2, *(D)}$

check for updates

Citation: Ferraguti, G.; Terracina, S.; Petrella, C.; Greco, A.; Minni, A.; Lucarelli, M.; Agostinelli, E.; Ralli, M.; de Vincentiis, M.; Raponi, G.; et al. Alcohol and Head and Neck Cancer: Updates on the Role of Oxidative Stress, Genetic, Epigenetics, Oral Microbiota, Antioxidants, and Alkylating Agents. Antioxidants 2022, 11, 145. https://doi.org/10.3390/ antiox11010145

Academic Editor: Cristina M. Furdui

Received: 27 October 2021

Accepted: 4 January 2022

Published: 11 January 2022

Publisher's Note: MDPI stays neutral with regard to jurisdictional claims in published maps and institutional affiliations.

Copyright: (C) 2022 by the authors. Licensee MDPI, Basel, Switzerland. This article is an open access article distributed under the terms and conditions of the Creative Commons Attribution (CC BY) license (https:// creativecommons.org/licenses/by/ $4.0 /)$.
1 Department of Experimental Medicine, Sapienza University of Rome, 00185 Rome, Italy; giampiero.ferraguti@uniroma1.it (G.F.); sergio.terracina@uniroma1.it (S.T.); marco.lucarelli@uniroma1.it (M.L.)

2 Institute of Biochemistry and Cell Biology, IBBC_CNR, 000185 Rome, Italy; carla.petrella@cnr.it (C.P.); mariagrazia.dicerto@cnr.it (M.G.D.C.); christian.barbato@cnr.it (C.B.)

3 Department of Sense Organs, Sapienza University of Rome, 00185 Rome, Italy; antonio.greco@uniroma1.it (A.G.); antonio.minni@uniroma1.it (A.M.); enzo.agostinelli@uniroma1.it (E.A.); massimo.ralli@uniroma1.it (M.R.); marco.devincentiis@uniroma1.it (M.d.V.)

4 Department of Public Health and Infectious Diseases, Sapienza University of Rome, 00185 Rome, Italy; giammarco.raponi@uniroma1.it

5 Department of Odontostomatological and Maxillofacial Sciences, Sapienza University of Rome, 00185 Rome, Italy; antonella.polimeni@uniroma1.it

6 SITAC, Società Italiana per il Trattamento dell'Alcolismo, 00184 Rome, Italy; mauro.ceccanti@uniroma1.it

7 SIFASD, Società Italiana Sindrome Feto-Alcolica, 00184 Rome, Italy

8 Department of Human Neurosciences, Sapienza University of Rome, 00185 Rome, Italy; brunella.caronti@uniroma1.it

9 Ministero dell'Interno, Dipartimento della Pubblica Sicurezza, Direzione Centrale di Sanità, Centro di Ricerche e Laboratorio di Tossicologia Forense, 00185 Rome, Italy; alessandro.mattia@poliziadistato.it

10 Department of Pediatrics, Sapienza University Hospital of Rome, 00185 Rome, Italy; luigi.tarani@uniroma1.it

* Correspondence: marco.fiore@cnr.it

\begin{abstract}
Head and neck cancer (HNC) concerns more than 890,000 patients worldwide annually and is associated with the advanced stage at presentation and heavy outcomes. Alcohol drinking, together with tobacco smoking, and human papillomavirus infection are the main recognized risk factors. The tumorigenesis of HNC represents an intricate sequential process that implicates a gradual acquisition of genetic and epigenetics alterations targeting crucial pathways regulating cell growth, motility, and stromal interactions. Tumor microenvironment and growth factors also play a major role in HNC. Alcohol toxicity is caused both directly by ethanol and indirectly by its metabolic products, with the involvement of the oral microbiota and oxidative stress; alcohol might enhance the exposure of epithelial cells to carcinogens, causing epigenetic modifications, DNA damage, and inaccurate DNA repair with the formation of DNA adducts. Long-term markers of alcohol consumption, especially those detected in the hair, may provide crucial information on the real alcohol drinking of HNC patients. Strategies for prevention could include food supplements as polyphenols, and alkylating drugs as therapy that play a key role in HNC management. Indeed, polyphenols throughout their antioxidant and anti-inflammatory actions may counteract or limit the toxic effect of alcohol whereas alkylating agents inhibiting cancer cells' growth could reduce the carcinogenic damage induced by alcohol. Despite the established association between alcohol and HNC, a concerning pattern of alcohol consumption in survivors of HNC has been shown. It is of primary importance to increase the awareness of cancer risks associated with alcohol consumption, both in oncologic patients and the general population, to provide advice for reducing HNC prevalence and complications.
\end{abstract}


Keywords: oral microbiota; alcohol; alkylating agents; epigenetics; growth factors; microenvironment; oxidative stress; polyphenols

\section{Introduction}

Worldwide, head and neck cancer (HNC) accounts for more than 890,000 cases and 450,000 deaths annually [1]. Head and neck cancer is a malignancy, associated with the advanced stage at presentation and heavy outcomes (mean 5 -year survival $<50 \%$ ), that occurs more often in the lips and oral cavity, nasopharynx, oropharynx, hypopharynx, and larynx; squamous cell carcinoma (SCC) represents the prevalent histology [2,3].

Alcohol abuse may result in significant mental [4-8] or physical health problems [9-12]. Furthermore, when consumed during gestation, it may induce severe damage to the newborns [13-20]. Alcohol is a well-known carcinogen compound but it is still underestimated in the general population, partially also because of the alcohol industry's extensive misrepresentation of evidence about the alcohol-related risk of cancer [21,22]. Alcohol drinking, together with tobacco smoking, and human papillomavirus (HPV) infection (Table 1) are HNC-recognized risk factors [23-26]. Interestingly, the role of alcohol in HNC seems to be broader than that of a simple risk factor, as suggested from recent findings which highlighted how significant inverse association exists between alcohol drinking and prognosis among HNC patients $[27,28]$. It has been reported that, in 2012, a total of 203,511 cases of the oral cavity, oropharyngeal, hypopharyngeal, and larynx cancer were attributable to alcohol consumption (179,559 men and 23,952 women) [29]. The proportion of HNC cases attributable to alcohol is still increasing, emphasizing the importance of alcohol consumption limitation to prevent HNC. Alcohol use among HNC survivors negatively impacts patient outcomes and is an important risk factor for recurrent and second primary tumors. Despite recommendations from several cancer societies, alcohol consumption remains a common problem in this population. [30]. The estimate of the real alcohol consumption (based not only on what the patient declared during the anamnesis) would be of support in consolidating the correlation with the onset of HNC.

Table 1. Major differences between HPV + and HPV - HNSCC (mainly related to alcohol abuse and smoke). Alcohol is a major determinant of aggressive HNCs. HNSCC, head and neck squamous cell carcinomas; HPV, human papillomavirus.

\begin{tabular}{ccc}
\hline & HPV + HNSCC & HPV - HNSCC \\
\hline Main risk factors & Sexual contact, HPV type 16 and 18 & Alcohol and smoking \\
\hline Tumor site & Oropharynx & Non-oropharyngeal sites \\
\hline Histopathology & $\begin{array}{c}\text { Basaloid, non-keratinizing, poorly } \\
\text { differentiated }\end{array}$ & Keratinizing, moderately differentiated \\
Main carcinogenic factor & Viral protein E6 and E7 action & $\begin{array}{c}\text { DNA damage and inaccurate DNA repair } \\
\text { promoted by alcohol catabolism and } \\
\text { smoke carcinogen components action }\end{array}$ \\
\hline Responsiveness to chemoradiation & Better than HPV - HNSCC & Worse than HPV + HNSCC \\
\hline Prognosis & Better than HPV - HNSCC & Worse than HPV + HNSCC \\
\hline Prevention & HPV vaccine, condom & Alcohol and smoking abstinence \\
\hline
\end{tabular}

This report aims to provide a summary and subsequent review of past studies, which highlights the evidence on the role of alcohol consumption, oral microbiota, and oxidative stress in head and neck cancer onset. 


\section{Head and Neck Cancer and Alcohol}

\subsection{Diagnosis and Treatments}

The HNC diagnosis usually includes laryngoscopy, imaging [Positron emission tomography / X-ray computed tomography (PET/CT) and magnetic resonance imaging (MRI)], and biopsy of the primary lesion [31-35]. As technology progresses, the development of non-invasive diagnostic tools in the field of head and neck oncology has been examined; the molecular analysis of tumor's genetic features based on circulating malignance derivatives, such as circulating tumor DNA, intact circulating tumor cells (CTCs), and exosomes in patients' blood, namely liquid biopsy, has become a concrete possible approach to improve diagnostics, treatment planning, and post-treatment surveillance in patients with the potentially curable disease [36-39].

Treatment possibilities include tumor resection (primary and/or secondary tumor), radical neck dissection, immunotherapy, radiotherapy, checkpoint inhibitors (mainly targeting the cytotoxic T-lymphocyte-associated protein 4 (CTLA-4)), programmed cell death protein 1 (PD-1), programmed death-ligand 1 (PD-L1), and chemotherapy [40-45]. Recently, it has been showing how, in locally advanced HNSCC, the CTCs and the circulating tumor microemboli (CTM) have a significant prognostic impact on the potential role as predictors of induction chemotherapy benefit [46].

It is believed that the majority of oral cancers develop from oral potentially malignant lesions (OPMLs) [47]. Though they can be easily detected during screening, risk stratification is difficult. During screening, clinicians often find it difficult to distinguish OPMLs from benign lesions, and predicting OPMLs at risk of malignant transformation could be particularly challenging [47]. DNA aneuploidy has been known to be a marker of malignancy in a number of sites, including the oral cavity [47]. Indeed, DNA ploidy and chromatin organization of cells collected from OPMLs can identify lesions at high risk of progression several years prior [48]. This non-invasive test would enable clinicians to triage high-risk OPMLs for closer follow-up, while low-risk lesions can undergo less frequent biopsies, reducing the burden on healthcare resources [48]. Quite interestingly, in a study on individuals with Fanconi anemia (people with a 500-fold to 700-fold elevated risk, much earlier onset, and limited therapeutic options for oral SCC compared with the general population), a careful inspection of the oral cavity associated with brush biopsy-based cytology could identify visible oral lesions, either malignant or potentially malignant, that warrant treatment [49].

\subsection{Alkylating Agents}

Because of the mentioned key role of genetic and epigenetic alterations in HNC, treatment protocols still include the use of alkylating agents (AAs). AAs are a heterogeneous class of drugs that interfere with the cell's DNA and inhibit cancer cells' growth, playing a major role in HNC [50]. These genotoxic agents modify the DNA by adding binding an alkyl group to the guanine base of DNA at the number 7 nitrogen atom of the purine ring, either directly or after metabolic conversion to reactive intermediates [51,52]. These drugs produce numerous side effects targeting many organs and apparats, such as the gastrointestinal tract, bone marrow, testicles, and ovaries; furthermore, most of the alkylating agents are also carcinogenic $[53,54]$. AAs still play a major role in the chemotherapeutic treatment of $\mathrm{HNC}$, especially cisplatin and methotrexate, in recurrent metastatic cancer, but the focus is gradually shifting to non-conventional systemic chemotherapy, especially targeted therapy and immunotherapy, which affect the tumor microenvironment and have a potentially favorable impact on HNC management [55-57].

\subsection{Alcohol Abuse Detection}

Despite the numerous proposed biomarkers in many studies, no laboratory test is sufficiently reliable alone to support a diagnosis of alcohol use disorder (AUD) [58,59]. Sensitivity and specificity should be high for alcohol abuse biomarkers, but in reality, they mostly fluctuate considerably and depend on the involved population. Furthermore, 
the ideal markers should reflect an individual's consumption of alcohol, both chronically (screening markers) and acutely (relapse markers), and, from this, the given title of "state" markers (in contrast to the "trait" markers that predict the predisposition to develop alcoholism) $[60,61]$. The use of long-term diagnostic tools gives crucial information on the real alcohol consumption of HNC patients so that a series of recently found useful biomarkers, which can be detected in the hair, is now in the spotlight: ethyl glucuronide (EtG), fatty acid ethyl esters (products of non-oxidative ethanol metabolism), phosphatidyl ethanol, acetaldehyde adducts to protein, and 5-hydroxytryptophol [18,62-64]. The main advantages of this sample material are that compounds with a relatively short lifetime in blood, but with a strong correlation to alcohol consumption, can be entrapped in the hair and are detectable for a longer time (also for years depending on the length of the hair) and at a relatively high concentration [64,65]. In particular, EtG and ethyl sulfate (EtS) are two non-oxidative ethanol metabolites (Figure 1) secreted by the liver which are mainly used as markers of alcohol intake related to incidents [66-71]. These two markers for recent alcohol intake can be detected in the blood for approximately $10 \mathrm{~h}$ after a small to moderate alcohol intake and up to 5 days after large and repeated alcohol intakes [67-69]. As the efficacy of these two tests has been demonstrated in multiple settings, it has been also suggested that EtG and EtS should be included in screening tests for injured or at-risk for alcohol abuse people (including pregnant women) to investigate the possible association between residual alcohol effects and injuries, and to verify alcohol abstinence in cases of substance-related disorders [72,73].

\section{Non-Oxidative Alcohol Metabolism}

\section{Fatty Acid Ethyl Ester (FAEE)}

\section{Phosphatidyl Ethanol}

\section{Ethyl Glucuronide (EtG)}

$$
\text { Ethyl Sulfate (EtS) }
$$

Keratin Matrices

\section{Peripheral Tissues and Organs}

Figure 1. In the liver, ethanol is metabolized via oxidative and non-oxidative (less than $1 \%$ ) ways. In the non-oxidative pathway, alcohol is finally processed as fatty acid ethyl ester (FAEE), phosphatidyl ethanol, ethyl glucuronide (EtG), and ethyl sulfate (EtS).

\section{Head and Neck Cancer Etiopathogenesis}

The main risk factors for HNC are tobacco, alcohol, HPV (especially 16, for oropharyngeal carcinoma), Epstein-Barr virus (EBV, for nasopharyngeal carcinoma), and HIV / AIDS; however, an association with hepatitis $\mathrm{C}$ and hepatitis $\mathrm{B}$ infection, as well as with proinflammatory diet (rich in red meat and fried foods) [74-78], has also been observed. Interestingly, evidence suggests a link between the renin-angiotensin system and HNC, and a recent study involving 5000 patients demonstrated that angiotensin II receptor blockers usage is associated with improved overall survival (OS) and cancer-specific survival among HNC patients with chronic kidney disease or hypertension [79]. It has been demonstrated that the combination of alcohol and smoking increases the risk in a synergic way, so that the probability of HNC onset increases dramatically when these two factors coexist [80-83]. On the other hand, the beneficial impact of cessation of alcohol consumption and tobacco smoking, as well as the protective effect of fruit and salad intake, which may modulate the deleterious effects of tobacco and alcohol, has been demonstrated [84-88]. Recently, it has been suggested that non-smoking and non-drinking oral SCC patients may 
represent a different entity with a limited role for HPV infection in carcinogenesis, but also that they are associated with worse outcomes when expressing HPV16 [89,90].

\subsection{Genomic Alterations}

The tumorigenesis of HNC represents an intricate sequential process that, while progressing from squamous hyperplasia through graded dysplasia to invasive carcinoma, implicates a gradual acquisition of genetic and epigenetic alterations, with genetic damage and repair and chromosomal loss and gain targeting the critical components of crucial genetic pathways regulating cell growth, motility, and stromal interactions [91,92]. The accumulation of alterations in crucial tumor suppressor genes (such as TP53 and CDKN2A) or signaling pathways (such as PI3K-AKT-mTOR and RAS-MAPK) is associated with the onset, progression, and poor prognosis of HPV-negative HNCs [93]. The most commonly disrupted pathways in HNCs patients are those involved in tumor protein 53 (TP53) and retinoblastoma (RB) activity, with wild-type mutations more commonly seen in HPVnegative patients [94-96]. The TP53 gene is a tumor suppressor transcription factor that regulates the cell cycle, preventing cell growth and promoting cell apoptosis in the presence of DNA damage. Over 50\% of the HNCs patients with TP53 pathway alterations present chromosomal loss at 17p (the site where the TP53 gene resides) $[97,98]$.

The RB pathway is mostly disrupted by the inactivation resulting mainly from promoter hypermethylation, gene mutation, or loss of heterozygosity $(\mathrm{LOH})$ of $\mathrm{p} 16^{\mathrm{INK} 4 \mathrm{~A}}$, a tumor suppressor protein that inhibits cyclin-dependent kinase (CDK) 4/6 and prohibits cells from entering the cell cycle. Up to $80 \%$ of HNSCCs present LOH at chromosomal region 9p21, where $\mathrm{p} 16^{\mathrm{INK} 4 \mathrm{~A}}$ resides [99-102]. The HPV-positive patients do not require the inactivation of $\mathrm{p} 16^{\mathrm{INK} 4 \mathrm{~A}}$ to have RB inhibition because the expression of the viral protein $\mathrm{E} 7$ causes the degradation of RB protein [103]. The HPV-positive tumors are distinctively characterized by frequent loss of TNF receptor-associated factor 3 (TRAF3) and amplification of E2F transcription factor 1 (E2F1), while HPV-negative tumors often present CDKN2A and TP53 alterations; focal deletions in other tumor suppressor genes (such as NSD1, FAT1, NOTCH1, and SMAD4); and frequent focal amplification of the genes encoding the EGFR, HER2, and FGFR1 receptor tyrosine kinases [104].

\subsection{Tumor Microenvironment}

Recently, the importance of the tumor microenvironment (TME) [105-108] has been emphasized, namely the result of factors associated with cancer, patient's characteristics (such as oral cavity microbiota, see paragraph below), immune system, and factors related to geographic origin, specifically embodied by the complex and dynamic interactions among the various cells as well as the balance of proangiogenic factors, tissue $\mathrm{pH}$, growth factors, and cytokine production changes over time $[109,110]$. Typically, HNC-TME is characterized by hypoxia (related to poor prognosis and resistance to radiation therapy) and immune cells infiltration, while an active tumor-stromal cross-talk is essential to promote cancer growth and invasion, with an important role played by cancer-associated fibroblasts (CAFs), chemokines, cytokines, and proliferative and inflammatory signal pathways [111-113]. The production of growth factors, such as vascular endothelial growth factor (VEGF), by both tumor cells and CAFs, causes the recruitment of endothelial cells which stimulate the neovascularization needed to bring oxygen and nutrients to sustain the tumor supporting the survival and self-renewal of cancer stem cells (CSCs) $[93,114]$. Meanwhile, IL-10 and IL1 induce interferon- $\gamma$ (IFN- $\gamma$ ) downregulation, which stimulates matrix metalloproteinases (MMPs) to support metastatic tumor cells' escape and angiogenesis [115].

\subsection{Growth Factors}

Many growth factors and their receptors have been extensively studied for both their role in HNC pathophysiology and possible target therapy development. One of the most studied is the epidermal growth factor receptor (EGFR) [116-120], a transmembrane tyrosine kinase receptor of the ErbB family that promotes multiple signaling pathways 
involved in tumor cell growth, evasion, angiogenesis, and invasion [121]. The EGFR activation in HNC is mainly driven by the high expression of its soluble ligands (EGF and transforming growth factor-alpha (TGF- $\alpha$ )), resulting in the dimerization of EGFR, the autophosphorylation of its intracellular kinase domain, and the stimulation of a proliferative and pro-survival intracellular signaling through the mitogen-activated protein kinase (MAPKs) cascade (as well as the PI3K-AKT-mTOR and JAK-STAT pathways) [122]. Even though more than $90 \%$ of HNCs overexpress EGFR (the expression progressively increases according to the histological malignant transformation, from hyperplasia to invasive carcinoma), which is associated with high local recurrence rate and poor survival, only a modest subgroup of HNCs shows amplified copy numbers or mutational activation of the EGFR gene, suggesting the existence of other mechanisms acting downstream on the pathways [123]. Targeted therapy specifically directed towards EGFR has been an area of keen interest in head and neck cancer research, as EGFR is potentially an integration point for convergent signaling [124]. However, despite the latest advancements in cancer diagnostics and therapeutics against EGFR, the survival rates of patients with advanced head and neck cancer remain disappointing due to the resistance to anti-EGFR therapies [124]. Interestingly, it has been demonstrated that $G$ protein-coupled receptors (often overexpressed in $\mathrm{HNC}$ ) ligands prostaglandin E2, bradykinin, and gastrin-releasing peptide activate EGFR signaling [125-127]. Another interesting therapeutic and prognostic target is the VEGF pathway (a member of the platelet-derived growth factor, PDGF, superfamily) [128-135], whose receptors are expressed both on endothelial cells and tumor cells and that include VEGF from A to E. VEGF (mainly VEGF-A) is often overexpressed in HNC and plays a key role as a mediator of angiogenesis, which supports tumorigenesis potentially modulating the tumor microenvironment $[136,137]$. On the other hand, hypoxia, one of the main components of the HNC microenvironment, is a major factor inducing VEGF expression through the expression of hypoxia-inducible factor- $\alpha$ (HIF-1 $\alpha)[138,139]$. The main angiogenesis downstream signal in HNC is usually mediated by VEGF-A and VEGFR-2; VEGF signaling can promote tumor cell proliferation, migration, immune system evasion, and cancer invasion (by activating key pathways such as the MAPK and PI3K$\mathrm{AKT}$ ), and can also play a role in chemotherapy resistance as it may induce autophagy that counteracts chemotherapy-induced stress [140,141]. Fibroblast growth factor receptor (FGFR) is often overexpressed in HNC, especially FGFR1, which is more commonly altered in the larynx and hypopharynx primary tumor locations. This plays an important role in the proliferation, survival, and migration of cancer cells, as well as angiogenesis [142-145]. Interestingly, it seems that ethanol-induced growth factors alterations are partially related to the oxidant capacity of the beverage, so that when ethanol is administered alone, it has different effects than when consumed in drinks with antioxidant properties (e.g., red wine) $[146,147]$.

Neurotrophins and their receptors have a nerve growth factor (NGF) which plays key roles in immune disorders [148-150], nerve cells growth and development [151-153], cardiovascular disorders [154-156], and psychiatric diseases [157-160]. Furthermore, it might regulate cell survival in HNC patients.

In particular, it has been demonstrated that the p 75 neurotrophin receptor, the lowaffinity receptor of nerve growth factor (NGF), is abnormally expressed in HNC patients and is related to NGF-independent therapy resistance, while high-affinity NGF receptor (tropomyosin receptor kinase A, TrkA) might transduce a survival signal of NGF, stimulating tumor cell survival after cell cycle arrest [161-164]. Interestingly, it has been demonstrated that alcohol drinking can modulate neurotrophins expression, causing both genetic and epigenetic effects $[164,165]$. 


\section{Cancerogenic Effects of Alcohol}

Alcohol is a known carcinogen and an independent risk factor for $\mathrm{HNC}$ but, when evaluating the relationship between alcohol and HNC (Figure 2), it is particularly important to take more account of those relevant studies that consider the risks from alcohol consumption in lifelong non-smokers to reduce the issues related to the effects of tobacco smoking $[82,166]$. Both smoke and alcohol exposure causes DNA damage and inaccurate DNA repair [93]. An etiological role for both ethanol and its primary oxidative metabolite acetaldehyde has been shown; in particular, the most relevant cancers considered to be causally related to alcoholic beverage consumption include those of the upper aerodigestive tract (oral cancer and cancers of the oropharynx, hypopharynx, larynx, and esophagus), the liver, the colon, the rectum, and the breast, with the greatest evidence for oral cavity, pharynx, esophagus, and larynx cancers $[167,168]$. While some papers reported that acetaldehyde rather than ethanol is the most important carcinogenic, i.e., a tumor initiator by binding of DNA and formation of DNA adducts, it has actually been proven that alcohol toxicity is caused both directly by ethanol and indirectly by its metabolic products, including the reactive oxygen species (ROS) produced during its biotransformation involving CYP2E1 [169-171]. It has been proposed that, regarding HNCs, alcohol might enhance the exposure of epithelial cells to carcinogens, but a variety of pathophysiological biomechanisms have also been linked to the direct or indirect tumorigenic effects of alcohol (oxidative stress, epigenetic modifications, DNA damage, inaccurate DNA repair, and the formation of DNA adducts) [121,172]. Furthermore, alcoholic beverages contain many different substances derived from fermentation (such as ethyl carbamate) which have proven to be carcinogenic to humans $[59,173]$. It has been demonstrated that heavy alcohol consumption may trigger somatic copy-number alterations of oncogenes and tumor suppressors frequently associated with HNC mutations (CDKN2A, FHIT, 11q13 region, HER2, 3q25-qter, and CSMD1) but, inversely to tobacco, it may not induce TP53 mutation [174]. Aldehyde dehydrogenase 1 (ALDH1), a component of alcohol metabolism major pathway located at chromosome 9q21.13, is considered a highly selective prognostic marker in HNC; indeed, ALDH1+ cells displayed resistance to radiotherapy and could generate tumors [175]. Unfortunately, there is no clear threshold effect of alcohol for both neoplasms and several non-neoplastic diseases [176].

\subsection{Oxidative Stress}

Physiologically, alcohol is mainly oxidized by the enzymes alcohol dehydrogenase (ADH), cytochrome P-450 2E1 (CYP2E1), and catalase to form acetaldehyde, which is subsequently oxidized by ALDH2 to produce acetate [177]. Among the ADH family, ADH1B plays a major role in ethanol oxidation, and polymorphisms in the ADH1B gene have been associated with upper aerodigestive tract cancer in Caucasians and the Japanese population, while individuals presenting with the $\mathrm{ADH}_{1} \mathrm{~B}^{*} 2$ allele (commonly observed in Asian population) show much higher (about 40 times) enzymatic activity than those with the wild-type $\mathrm{ADH}_{1} \mathrm{~B}^{*} 1$ allele, resulting in high acetaldehyde exposure but lower risk of cancer because of the "flushing response" to alcohol associated with facial flushing, palpitations, and headaches, as well as other unpleasant symptoms that prevent them from heavy drinking [178-181]. Similarly, and often concurrently, the enzyme encoded by ALDH2 2 (also common in the Asian population) has a lysine for glutamate substitution at residue 487 , resulting in a loss of activity so that ALDH2*2 $/{ }^{*} 2$ homozygotes (and to a lesser extent in ALDH2* $1 /{ }^{*} 2$ heterozygosis) exhibit a flushing response to alcohol that prevent them from alcohol drinking [182-184]. The induction of CYP2E1 expression is one of the key pathways whereby ethanol can lead to the generation of ROS, altering the intracellular redox state, and ultimately leading to a global increase in oxidative stress and neuronal cells death by the oxidation of proteins, lipids, and DNA $[185,186]$. ROS (superoxide, hydrogen peroxide, hydroxyl radicals, and singlet oxygen) can oxidize cellular DNA, leading to several alterations, including oxidized bases, single-/double-stranded breaks, and the generation of oxidative DNA adducts, which can cause genetic mutations resulting in cellular 
immortalization and clonal expansion, ultimately leading to cancer [104]. Interestingly, it has been found that the frequently found mutations in the genes encoding nuclear factor erythroid 2-related factor 2 (NFE2L2) and Kelch-like ECH-associated protein 1 (KEAP1), i.e., key regulators of oxidative stress, occur exclusively in HPV-negative HNC [104]. As mentioned, ROS attack all cellular macromolecules, not only DNA, and in particular, they initiate lipid peroxidation and damage to cell membranes producing crotonaldehyde, acrolein, 4-hydroxy-2-nonenal, and malondialdehyde, which are reactive substances that damage DNA through the formation of exocyclic adducts [187-189]. Another possible cause of oxidative stress is the mitochondrial dysfunction associated with alcohol chronic ingestion [190,191]. Increased activity of the enzyme nicotinamide adenine dinucleotide phosphate oxidase (NOX) is a key source of ROS production so that co-treatment with NOX inhibitors is considered useful to prevent ethanol-induced increases in NOX activity, ROS generation, and oxidative DNA damage $[190,192,193]$. In murine experiments, it has been demonstrated that antioxidant vitamin E (alpha-tocopherol) adjusts the levels of anti-apoptotic and pro-apoptotic proteins and corrects organs alterations and DNA damage [194-197].

Many other antioxidants have shown promising therapeutic effects against alcohol pro-oxidative and mutagenic action, mainly in rodents, including ascorbic acid (vitamin C), beta-carotene, black ginseng, EUK-134 (synthetic superoxide dismutase plus catalase mimetic), folic acid, melatonin, $\mathrm{N}$-acetylcysteine, phenyl butyl nitrone, pycnogenol, silymarin, resveratrol, hydroxytyrosol, and superoxide dismutase [185,198-207].

\subsection{Oral Microbiota}

Recent scientific investigations have focused on studying the role of the oral microbiota in the pathogenesis of upper respiratory tract tumors [208-212]. While it is clear that the presence of localized infections can negatively impact the outcome of oral cancer, it is not equally clear whether or not the existence of dysbiosis is, in itself, a cause or consequence of the presence of the tumor. This is mainly due to the fact that a few studies analyze the modification of the microbial population in the early stages of tumor onset $[213,214]$. As regards the impact of alcohol consumption on the microbial population of the oral cavity, a large study conducted on the American population has shown that, especially in heavy drinkers, there is an alteration of the microbial composition [215]. In particular, there is a significant decrease in lactobacilli, whose presence is associated with beneficial, antiinflammatory, and antioxidant effects. In particular, in the oral cavity, the administration of probiotics based on Lactobacilli has been shown to inhibit the proliferation of pathogens and reduce gingival inflammation $[216,217]$. 


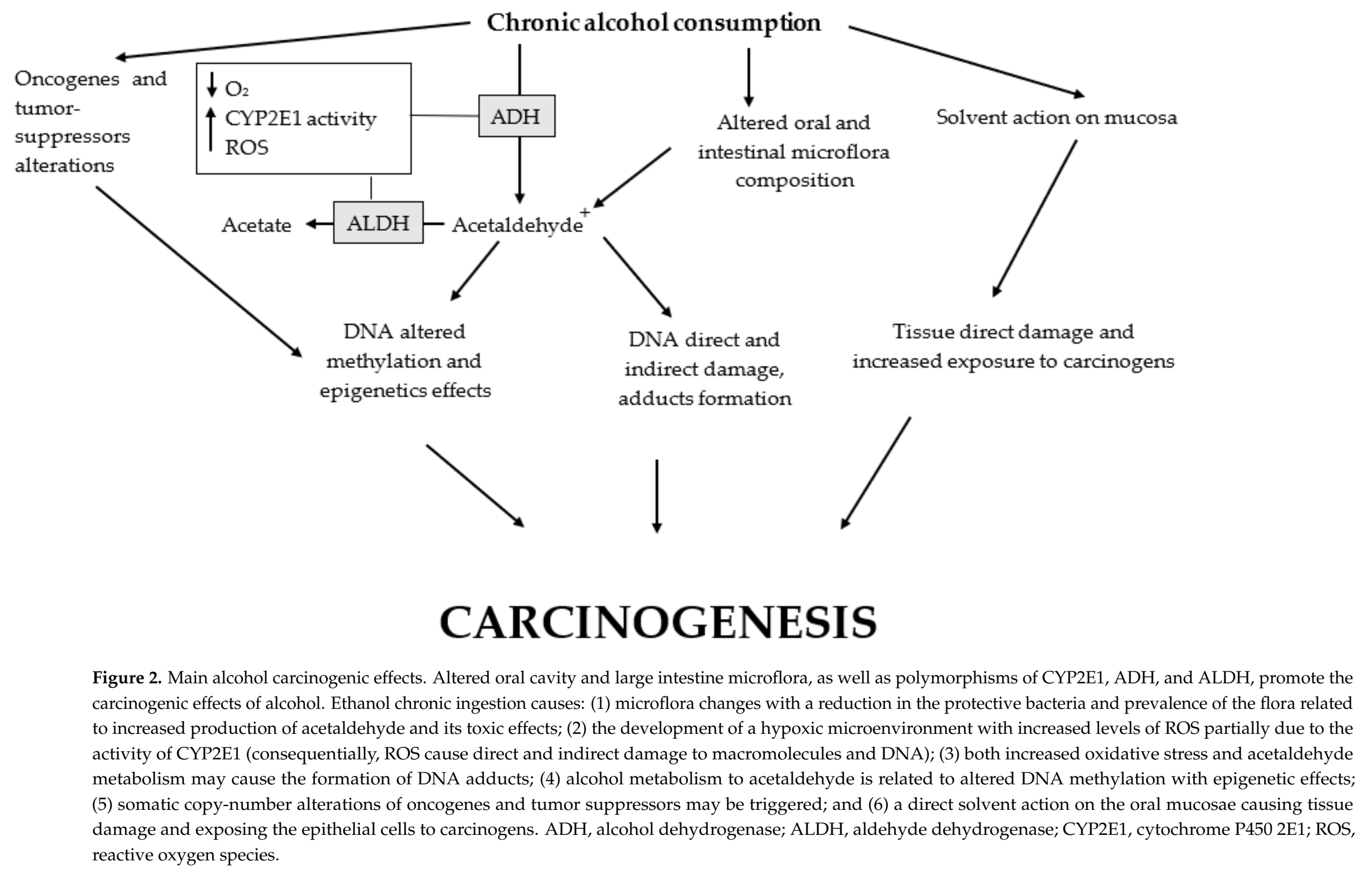


As for the interaction between alcohol, oral microbiota, and laryngeal tumors, certain studies highlight the potential role of some microorganisms in mediating the carcinogenic effect of alcohol [218,219]. Indeed, acetaldehyde, the main product of alcohol metabolism, with proven carcinogenic effects, seems to be produced locally by the action of microorganisms, including bacteria and yeasts. Acetaldehyde formation has been described in human mouth washings and bronchopulmonary washings in vitro, and it was reduced by using antibiotics, suggesting an oral bacterial origin [220,221]. Among the bacterial species normally habiting the oral cavity, genus Neisseria has particularly high ADH activity and produces significant amounts of acetaldehyde when cultured in the presence of ethanol in vitro [222]. The ability to produce acetaldehyde was more than 100-fold higher than that produced by any other genera studied. Additionally, alcohol ingestion influences the microbial composition of the oral cavity, resulting in an augmented amount of Neisseria. Although Neisseria present in the ordinary oral microflora is non-pathogenic, these results suggest that it could be a local source of carcinogenic acetaldehyde and, thus, potentially participates in the alcohol-related carcinogenesis in human oral cancer. Among Neisseria species, N. subflava isolated from patients has shown ADH activity and the ability to produce acetaldehyde from ethanol [222]. A recent study conducted in Japan explored the salivary microbiota profiles of healthy adults in order to evaluate the acetaldehyde production in the oral cavity [223]. A marked difference in the salivary acetaldehyde production ability, depending on the oral microbiota of healthy adults was found, but this was independent of the abundance of Neisseria species in the salivary microbiota. These data confirm the ability of Neisseria spp. to locally metabolize ethanol [223].

Acetaldehyde production from ethanol by oral streptococci has been also demonstrated in the study conducted by Kurkivuori et al. [222]. Authors demonstrated that diverse strains showed a significantly different ability to metabolize ethanol, as demonstrated by experiments conducted by using Streptococcus salivarius, Streptococcus intermedius, and Streptococcus mitis that produced high amounts of acetaldehyde, from different ethanol concentrations. Based on such pieces of evidence, these bacteria could be considered dangerous in heavy drinkers [224,225].

Finally, the production of carcinogenic acetaldehyde by Candida spp. has been suggested. In particular, both Candida albicans and non-albicans contribute to epithelial dysplasia and oral carcinogenesis, by producing mutagenic amounts of acetaldehyde, from glucose and ethanol [226-229]. Indeed, an interesting paper by Nieminen and co-workers demonstrated the ability of Candida glabrata to produce acetaldehyde, from glucose and ethanol, supporting a role in the development of oral cancer [230].

\subsection{Acetaldehyde DNA Adducts}

Alcohol and tobacco carcinogens and their metabolites can bind covalently to DNA, resulting in the formation of DNA adducts [231-237] which, if unrepaired, can cause miscoding and permanent mutations. These can then activate oncogenes or inactivate tumor suppressor genes driving the cancerogenesis process (it may be a major initiating event of chemical carcinogenesis) [238-240]. The main DNA adduct in the human body is a Schiff base N2-ethylidene-2-deoxyguanosine adduct (which may be converted by reducing agents to N2-ethyl-2'-deoxyguanosine altering DNA synthesis), though products are also observed in reactions with deoxyadenosine (dA) and deoxycytidine (dC) [241,242]. As mentioned, polymorphisms of the genes which encode enzymes (e.g., ALDH2) for alcohol metabolism impact ethanol oxidizing capacity, leading to the accumulation of acetaldehyde as well as an increased risk for developing alcohol-induced complications, such as HNC [243]. The key mechanism for alcohol-induced adducts involves acetaldehyde, whose cancerogenic effects are connected to multiple paths; it interferes with DNA synthesis and repair, causes mucosa lesions, inhibits O6-methyl-guanylyltransferase (an enzyme important for the repair of adducts caused by alkylating agents), and covalently binds to DNA-forming adducts [244,245]. Despite the interest, it is still unclear whether these alcohol-related DNA adducts are true factors or initiators of cancer, but it has been suggested that measuring 
aldehyde-induced DNA and protein adducts produced during alcohol metabolism may allow earlier detection of alcohol abuse disorders and complications [246].

\subsection{Epigenetics}

Epigenetics refers to the "study of heritable changes in gene expression that occur without a change in the DNA sequence" so that epigenetic mechanisms consent to an ulterior transcriptional control that regulates how genes are expressed [247-250]. In addition to genetic alterations, epigenetic changes (mainly DNA methylation, histone methylation, and deacetylation) also play an important role in driving HNC oncogenesis [251-257]. On the other hand, epigenetic mechanisms are strongly related to alcoholism and alcohol drinking disorders $[165,258,259]$. In HNC, DNA hypermethylation causes epigenetic silencing of tumor suppressor genes (especially those involved in DNA repair, cell cycle control, apoptosis, angiogenesis, cell-cell interaction, and metastasis) which is considered a specific marker of cancer $[250,260,261]$. On the other hand, despite the presence of regional promoter hypermethylation, $\mathrm{HNC}$ reveals global genomic hypomethylation in about $67 \%$ of cases, and the degree of global hypomethylation (measured by the level of methylation of repetitive sequences across the genome) is associated with smoking history, alcohol use and tumor stage [262,263]. It has been demonstrated that the etiologic heterogeneity of HNC is reflected in specific patterns of molecular epigenetic alterations within the tumors and that the DNA methylation profiles and gene expression may hold clinical potential $[264,265]$. Indeed, gene expression profiles are strongly associated with the development of $\mathrm{HNC}$, and DNA methyltransferase 3B (DNMT3B, a de novo DNA methyltransferase) polymorphism has been identified as one of the most important factors associated with these tumors because of its connection with $\mathrm{CpG}$ island methylator phenotype (CIMP), a possible early event during HNC development $[251,266,267]$. Studies evaluating increased promoter methylation, as well as the resulting downregulated expression of key tumor suppressor genes from normal mucosa to premalignant lesions and $\mathrm{HNC}$, included many genes such as cyclin-dependent kinase inhibitor $2 \mathrm{~A}(\mathrm{CDKN} 2 \mathrm{~A})$, retinoic acid receptor beta (RAR $\beta$, which mediates epithelial cell differentiation), deleted in colorectal cancer netrin 1 receptor (DCC), O-6-Methylguanine-DNA methyltransferase (MGMT, involved in the repair of DNA damage from tobacco carcinogens), $\mathrm{p} 16^{\mathrm{Ink} 4}, \mathrm{p} 14^{\mathrm{ARF}}$, endothelin receptor type $\mathrm{B}$ (EDNRB), E-cadherin (CDH1), deleted in lung and esophageal cancer 1 (DLCE1), and NDRG family member 2 (NDRG2) [255,268-271]. Interestingly, it has been demonstrated that IL-6-induced inflammation promotes HNC tumorigenesis by altering global long interspersed nuclear element-1 (LINE-1) hypomethylation, while concurrent hypermethylation of multiple tumor suppressor genes by IL-6 suggests that epigenetic gene silencing may be a vital consequence of head and neck tissues chronic inflammation [272].

\section{Strategies for Prevention \\ Polyphenols}

It has been demonstrated that the content of antioxidants (polyphenols) in alcoholic drinks (i.e., resveratrol in the red wine) may counteract the toxic effect of alcohol in animal models [198,199,273-279]. In particular, polyphenols are natural, synthetic, or semisynthetic organic molecules characterized by several hydroxyl groups on aromatic rings (phenolic groups), presenting neuroprotective effects and a capacity to control oxidative stress, inflammation, apoptosis, and mitochondrial dysfunction. They can be divided into four main groups: phenolic acids, flavonoids, stilbenes, and lignans $[274,280,281]$. The Mediterranean diet is a mainstay of nutritional therapeutic and preventive programs in HNC because of the rich presence of foods abundant in polyphenols, such as olives and olive oil, as well as fresh and processed fruits and vegetables, leguminous plants, cereals, herbs, spices, tea, coffee, wine, and beer [282-285]. A proper diet is one of the major factors contributing to good health and is directly related to the general condition of the organism $[273,286]$. Polyphenols are converted and absorbed mainly in the oral cavity and stomach; in the large intestine, the remaining polyphenols are further modified by bacterial 
enzymes (e.g., glycosides, esters, etc.) to obtain lower-weight metabolites which are easier to absorb. The metabolites then circulate within the blood, bind to proteins (mainly albumin), and conjugate in the liver and kidneys, before finally being eliminated in urines and feces [287]. Plant polyphenols are natural antioxidants which, at the same time, also exhibit prooxidant properties (also important for polyphenols anticancer properties), catalyzing oxidative DNA cleavage particularly in the presence of transition metal ions such as copper and iron [199,288]. Polyphenols in oils, especially extra virgin olive oil, are effective in both preventing cancer and in reducing toxicity and carcinogenicity of alcohol, mainly due to its antioxidant properties [276,289-291]. In an dimethyl-benzanthracene-induced hamster model of carcinogenesis, green tea lowered detectable tumors by almost $35 \%$ and tumor volume by almost $57 \%$, while tea (Camellia sinensis) constituents inhibited carcinogenesis of various tumors, including HNC, by inducing apoptosis and reducing cell proliferation, with a major role played by epigallocathechin-3 gallate (ECG) and theaflavins through inhibiting mitogen-activated protein kinases, as well as signaling growth factor, cyclin-dependent kinases, including topoisomerase-1 and many other potential targets [292,293].

Polyphenols are also present in alcoholics, such as red wine (whose main polyphenol is resveratrol) and beer, with evidence that moderate wine consumption may decrease the risk of several cancers, including colon, basal cell carcinoma, ovarian (while breast cancer is promoted), and prostate cancer; however, it is essential to maintain adequate balance to avoid the negative and cancerogenic effects due to the ethanol present in these beverages, mainly because these results are obtained from studies on human cancer cells in culture, murine models, or as conclusions from epidemiological studies, rather than from clinical trials with cancer patients [294,295]. The wine may inhibit carcinogenesis by acting as an antioxidant, anti-inflammatory, antimutagen, antimetastatic, anti-angiogenic, antidifferentiation, antiproliferative, and proapoptotic agent which can modulate signal transduction, immune response, transcription factors, growth factors, cytokines, caspases, interleukins (ILs), prostaglandin synthesis, and cell cycle-regulating proteins [296].

\section{Discussion}

In this narrative review, we analyzed literature evidence concerning the role of alcohol consumption in HNC onset. Though alcohol is not the sole risk factor for HNC, it plays a major role in the etiopathogenesis of both primary tumors and their recurrences. Alcohol carcinogenicity is mainly caused both directly by ethanol and indirectly by its metabolic products; it enhances intracellular oxidative stress and the exposure of epithelial cells to carcinogens, and is associated with epigenetic mutations, DNA damage, and inaccurate DNA repair related to the formation of DNA adducts [169-172,258]. Alcohol consumption may trigger somatic copy number alterations of oncogenes and tumor suppressors which are frequently associated with HNC mutations [174]. Unfortunately, there is no clear threshold effect of alcohol for oncogenic patients [176].

Since the relationship between alcohol and HNC has been largely established, longterm markers of alcohol consumption, especially those detected in the hair, can give crucial information on the real alcohol drinking habits of HNC patients $[63,64]$. Furthermore, many prognostic markers related to alcoholism, especially those linked to the polymorphisms of ethanol metabolic pathway components, have been suggested for the detection and monitoring of HNC [109]. With this knowledge on the etiopathogenesis of HNC and its relation to alcohol-induced oxidative stress and genetic-epigenetic alterations, more attention could be focused on the role of polyphenols and alkylating agents for patient management, especially in the case of heavy drinkers $[188,279,287]$.

\section{Conclusions}

Alcohol abuse is a dangerous condition which affects both females and males, causing significant dangerous effects, especially in the long term. Despite the established association between alcohol and HNC, a concerning pattern of alcohol consumption, both in the general population and in survivors of $\mathrm{HNC}$, has been shown. It is of primary importance to address 
the problem of alcohol drinking, both in oncologic patients and the general population, to rectify misconducts and to reduce HNC prevalence and complications.

Author Contributions: Conceptualization: G.F., S.T., C.P., A.M. (Antonio Minni), G.R., A.P., M.C. and M.F.; resources: A.G., M.d.V., E.A., M.R., B.C., M.G.D.C., C.B., A.M. (Antonio Minni), M.L., A.M. (Alessandro Mattia) and B.C.; writing-original draft preparation: G.F., S.T., C.P., M.R., G.R., L.T. and M.F.; writing—review \& editing: G.F., S.T., C.P., M.R., G.R., L.T., A.M. (Alessandro Mattia), M.C. and M.F.; visualization: S.T., C.P., M.F. and B.C.; supervision: M.F., A.P., M.L., A.G., M.d.V. and M.C. All authors have read and agreed to the published version of the manuscript.

Funding: This research received no external funding.

Acknowledgments: Authors thank IBBC-CNR, SITAC and Sapienza Universita' di Roma, Italy.

Conflicts of Interest: The authors declare no conflict of interest, financial or otherwise.

\section{References}

1. Sung, H.; Ferlay, J.; Siegel, R.L.; Laversanne, M.; Soerjomataram, I.; Jemal, A.; Bray, F. Global Cancer Statistics 2020: GLOBOCAN Estimates of Incidence and Mortality Worldwide for 36 Cancers in 185 Countries. CA Cancer J. Clin. 2021, 71, 209-249. [CrossRef]

2. Kawakita, D.; Matsuo, K. Alcohol and head and neck cancer. Cancer Metastasis Rev. 2017, 36, 425-434. [CrossRef]

3. De França, G.M.; da Silva, W.R.; Medeiros, C.K.S.; Júnior, J.F.; Santos, E.D.M.; Galvão, H.C. Five-year survival and prognostic factors for oropharyngeal squamous cell carcinoma: Retrospective cohort of a cancer center. Oral Maxillofac. Surg. 2021, 1-9. [CrossRef] [PubMed]

4. Ledda, R.; Battagliese, G.; Attilia, F.; Rotondo, C.; Pisciotta, F.; Gencarelli, S.; Greco, A.; Fiore, M.; Ceccanti, M.; Attilia, M.L. Drop-out, relapse and abstinence in a cohort of alcoholic people under detoxification. Physiol. Behav. 2019, 198, 67-75. [CrossRef]

5. Ceccanti, M.; Hamilton, D.; Coriale, G.; Carito, V.; Aloe, L.; Chaldakov, G.; Romeo, M.; Iannitelli, A.; Fiore, M. Spatial learning in men undergoing alcohol detoxification. Physiol. Behav. 2015, 149, 324-330. [CrossRef] [PubMed]

6. Ceccanti, M.; Coriale, G.; Hamilton, D.A.; Carito, V.; Coccurello, R.; Scalese, B.; Ciafrè, S.; Codazzo, C.; Messina, M.P.; Chaldakov, G.N.; et al. Virtual Morris task responses in individuals in an abstinence phase from alcohol. Can. J. Physiol. Pharmacol. 2018, 96, 128-136. [CrossRef] [PubMed]

7. Coriale, G.; Battagliese, G.; Pisciotta, F.; Attilia, M.L.; Porrari, R.; De Rosa, F.; Vitali, M.; Carito, V.; Messina, M.P.; Greco, A.; et al. Behavioral responses in people affected by alcohol use disorder and psychiatric comorbidity: Correlations with addiction severity. Ann. Dell'Istituto Super. Sanita 2019, 55, 131-142. [PubMed]

8. Coriale, G.; Gencarelli, S.; Battagliese, G.; Delfino, D.; Fiorentino, D.; Petrella, C.; Greco, A.; Ralli, M.; Attilia, M.L.; Messina, M.P.; et al. Physiological Responses to Induced Stress in Individuals Affected by Alcohol Use Disorder with Dual Diagnosis and Alexithymia. Clin. Ter. 2020, 171, e120-e129. [PubMed]

9. Ceci, F.M.; Ceccanti, M.; Petrella, C.; Vitali, M.; Messina, M.P.; Chaldakov, G.N.; Greco, A.; Ralli, M.; Lucarelli, M.; Angeloni, A.; et al. Alcohol Drinking, Apolipoprotein Polymorphisms and the Risk of Cardiovascular Diseases. Curr. Neurovascular Res. 2021, 18, 150-161. [CrossRef] [PubMed]

10. Ceccanti, M.; Inghilleri, M.; Attilia, M.L.; Raccah, R.; Fiore, M.; Zangen, A. Deep TMS on alcoholics: Effects on cortisolemia and dopamine pathway modulation. A pilot study. Can. J. Physiol. Pharmacol. 2015, 93, 283-290. [CrossRef]

11. Ceccanti, M.; Sasso, G.F.; Nocente, R.; Balducci, G.; Prastaro, A.; Ticchi, C.; Bertazzoni, G.; Santini, P.; Attilia, M.L. Hypertension in early alcohol withdrawal in chronic alcoholics. Alcohol Alcohol. 2005, 41, 5-10. [CrossRef]

12. Ceccanti, M.; Attili, A.; Balducci, G.; Attilia, F.; Giacomelli, S.; Rotondo, C.; Sasso, G.F.; Xirouchakis, E.; Attilia, M.L. Acute alcoholic hepatitis. J. Clin. Gastroenterol. 2006, 40, 833-841. [CrossRef]

13. Fiore, M.; Petrella, C.; Coriale, G.; Rosso, P.; Fico, E.; Ralli, M.; Greco, A.; De Vincentiis, M.; Minni, A.; Polimeni, A.; et al. Markers of Neuroinflammation in the Serum of Prepubertal Children with Fetal Alcohol Spectrum Disorders. CNS Neurol. Disord. Drug Targets 2021, 20, 1. [CrossRef]

14. Terracina, S.; Ferraguti, G.; Tarani, L.; Messina, M.P.; Lucarelli, M.; Vitali, M.; De Persis, S.; Greco, A.; Minni, A.; Polimeni, A.; et al. Transgenerational Abnormalities Induced by Paternal Preconceptual Alcohol Drinking. Findings from Humans and Animal Models. Curr. Neuropharmacol. 2021, 19, 1. [CrossRef] [PubMed]

15. Ceccanti, M.; Coccurello, R.; Carito, V.; Ciafrè, S.; Ferraguti, G.; Giacovazzo, G.; Mancinelli, R.; Tirassa, P.; Chaldakov, G.N.; Pascale, E.; et al. Paternal alcohol exposure in mice alters brain NGF and BDNF and increases ethanol-elicited preference in male offspring. Addict. Biol. 2016, 21, 776-787. [CrossRef] [PubMed]

16. Ferraguti, G.; Codazzo, C.; Petrella, C.; Coccurello, R.; Ceccanti, M.; Fiore, M. Brainstem expression of SLC6A4, HTR2C, NGF, BDNF, TRKANGF, TRKBBDNF and P75NTR following paternal alcohol exposure in the male mouse. Biomed. Rev. 2020, $31,75-89$. [CrossRef]

17. Carito, V.; Ceccanti, M.; Ferraguti, G.; Coccurello, R.; Ciafrè, S.; Tirassa, P.; Fiore, M. NGF and BDNF Alterations by Prenatal Alcohol Exposure. Curr. Neuropharmacol. 2019, 17, 308-317. [CrossRef] [PubMed] 
18. Ferraguti, G.; Merlino, L.; Battagliese, G.; Piccioni, M.G.; Barbaro, G.; Carito, V.; Messina, M.P.; Scalese, B.; Coriale, G.; Fiore, M.; et al. Fetus morphology changes by second-trimester ultrasound in pregnant women drinking alcohol. Addict. Biol. 2020, 25, e12724. [CrossRef]

19. Coriale, G.; Fiorentino, D.; Di Lauro, F.; Marchitelli, R.; Scalese, B.; Fiore, M.; Maviglia, M.; Ceccanti, M. Fetal Alcohol Spectrum Disorder (FASD): Neurobehavioral profile, indications for diagnosis and treatment. Riv Psichiatr. 2013, 48, 359-369. [CrossRef]

20. Fetal alcohol spectrum disorders awareness in health professionals: Implications for psychiatry. Riv. Psichiatr. 2020, 55, 79-89.

21. Kiviniemi, M.T.; Orom, H.; Hay, J.L.; Waters, E.A. Limitations in American adults' awareness of and beliefs about alcohol as a risk factor for cancer. Prev. Med. Rep. 2021, 23, 101433. [CrossRef]

22. Petticrew, M.; Hessari, N.M.; Knai, C.; Weiderpass, E. How alcohol industry organisations mislead the public about alcohol and cancer. Drug Alcohol Rev. 2018, 37, 293-303. [CrossRef] [PubMed]

23. Maso, L.D.; Torelli, N.; Biancotto, E.; Di Maso, M.; Gini, A.; Franchin, G.; Levi, F.; La Vecchia, C.; Serraino, D.; Polesel, J. Combined effect of tobacco smoking and alcohol drinking in the risk of head and neck cancers: A re-analysis of case-control studies using bi-dimensional spline models. Eur. J. Epidemiol. 2016, 31, 385-393. [CrossRef] [PubMed]

24. Hashibe, M.; Brennan, P.; Benhamou, S.; Castellsagué, X.; Chen, C.; Curado, M.P.; Dal Maso, L.; Daudt, A.W.; Fabianova, E.; Wünsch-Filho, V.; et al. Alcohol Drinking in Never Users of Tobacco, Cigarette Smoking in Never Drinkers, and the Risk of Head and Neck Cancer: Pooled Analysis in the International Head and Neck Cancer Epidemiology Consortium. J. Natl. Cancer Inst. 2007, 99, 777-789. [CrossRef] [PubMed]

25. Applebaum, K.M.; Furniss, C.S.; Zeka, A.; Posner, M.R.; Smith, J.F.; Bryan, J.; Eisen, E.A.; Peters, E.S.; McClean, M.D.; Kelsey, K.T. Lack of Association of Alcohol and Tobacco with HPV16-Associated Head and Neck Cancer. J. Natl. Cancer Inst. 2007, 99, 1801-1810. [CrossRef] [PubMed]

26. Gillison, M.L.; Chaturvedi, A.K.; Anderson, W.F.; Fakhry, C. Epidemiology of Human Papillomavirus-Positive Head and Neck Squamous Cell Carcinoma. J. Clin. Oncol. 2015, 33, 3235-3242. [CrossRef] [PubMed]

27. Sawabe, M.; Ito, H.; Oze, I.; Hosono, S.; Kawakita, D.; Tanaka, H.; Hasegawa, Y.; Murakami, S.; Matsuo, K. Heterogeneous impact of alcohol consumption according to treatment method on survival in head and neck cancer: A prospective study. Cancer Sci. 2016, 108, 91-100. [CrossRef]

28. Kawakita, D.; Oze, I.; Hosono, S.; Ito, H.; Watanabe, M.; Yatabe, Y.; Hasegawa, Y.; Murakami, S.; Tanaka, H.; Matsuo, K. Prognostic Value of Drinking Status and Aldehyde Dehydrogenase 2 Polymorphism in Patients with Head and Neck Squamous Cell Carcinoma. J. Epidemiol. 2016, 26, 292-299. [CrossRef]

29. Praud, D.; Rota, M.; Rehm, J.; Shield, K.; Zatoński, W.; Hashibe, M.; La Vecchia, C.; Boffetta, P. Cancer incidence and mortality attributable to alcohol consumption. Int. J. Cancer 2016, 138, 1380-1387. [CrossRef]

30. Teckie, S.; Wotman, M.; Marziliano, A.; Orner, D.; Yi, J.; Mulvany, C.; Ghaly, M.; Parashar, B.; Diefenbach, M.A. Patterns of alcohol use among early head and neck cancer survivors: A cross-sectional survey study using the alcohol use disorders identification test (AUDIT). Oral Oncol. 2021, 119, 105328. [CrossRef]

31. Koo, K.; Harris, R.; Wiesenfeld, D.; Iseli, T.A. A role for panendoscopy? Second primary tumour in early stage squamous cell carcinoma of the oral tongue. J. Laryngol. Otol. 2015, 129, S27-S31. [CrossRef]

32. Metzger, K.; Horn, D.; Pfeiffer, T.; Moratin, J.; Kansy, K.; Ristow, O.; Engel, M.; Hoffmann, J.; Freier, K.; Schaible, A.; et al. Is panendoscopy a necessary staging procedure in patients with lacking risk factors and oral squamous cell carcinoma? $\mathrm{J}$. Cranio-Maxillofac. Surg. 2019, 47, 1968-1972. [CrossRef]

33. Koerdt, S.; Raguse, J.-D.; Neumann, F.; Beck-Broichsitter, B.; Kreutzer, K.; Neumann, K.; Heiland, M.; Doll, C. Value of Panendoscopy in the Identification of Synchronous Malignancies in Patients Suffering from Oral Squamous Cell Carcinoma Without Clinical Signs of a Second Primary Tumor. Anticancer. Res. 2021, 41, 2039-2044. [CrossRef]

34. Dittberner, A.; Ziadat, R.; Hoffmann, F.; Pertzborn, D.; Gassler, N.; Guntinas-Lichius, O. Fluorescein-Guided Panendoscopy for Head and Neck Cancer Using Handheld Probe-Based Confocal Laser Endomicroscopy: A Pilot Study. Front. Oncol. 2021, 11, 2186. [CrossRef]

35. Sheppard, S.C.; Borner, U.; Wartenberg, M.; Giger, R.; Nisa, L. Diagnostic use of fine-needle aspiration cytology and core-needle biopsy in head and neck sarcomas. Head Neck 2021, 43, 1939-1948. [CrossRef]

36. Schmidt, H.; Kulasinghe, A.; Kenny, L.; Punyadeera, C. The development of a liquid biopsy for head and neck cancers. Oral Oncol. 2016, 61, 8-11. [CrossRef] [PubMed]

37. Economopoulou, P.; Kotsantis, I.; Kyrodimos, E.; Lianidou, E.; Psyrri, A. Liquid biopsy: An emerging prognostic and predictive tool in Head and Neck Squamous Cell Carcinoma (HNSCC). Focus on Circulating Tumor Cells (CTCs). Oral Oncol. 2017, 74, 83-89. [CrossRef] [PubMed]

38. Payne, K.; Spruce, R.; Beggs, A.; Sharma, N.; Kong, A.; Martin, T.; Parmar, S.; Praveen, P.; Nankivell, P.; Mehanna, H. Circulating tumor DNA as a biomarker and liquid biopsy in head and neck squamous cell carcinoma. Head Neck 2018, 40, 1598-1604. [CrossRef] [PubMed]

39. Marcus, C.; Sheikhbahaei, S.; Shivamurthy, V.K.N.; Avey, G.; Subramaniam, R.M. PET Imaging for Head and Neck Cancers. Radiol. Clin. N. Am. 2021, 59, 773-788. [CrossRef]

40. Gogna, S.; Kashyap, S.; Gupta, N. Neck Cancer Resection and Dissection; StatPearls Publishing: Treasure Island, FL, USA, 2021.

41. Pharaon, R.R.; Xing, Y.; Agulnik, M.; Villaflor, V.M. The Role of Immunotherapy to Overcome Resistance in Viral-Associated Head and Neck Cancer. Front. Oncol. 2021, 11, 649963. [CrossRef] 
42. Cripps, C.; Winquist, E.; Devries, M.C.; Stys-Norman, D.; Gilbert, R.; the Head and Neck Cancer Disease Site Group. Epidermal Growth Factor Receptor Targeted Therapy in Stages III and IV Head and Neck Cancer. Curr. Oncol. 2010, 17, 37-48. [CrossRef] [PubMed]

43. Kaidar-Person, O.; Gil, Z.; Billan, S. Precision medicine in head and neck cancer. Drug Resist. Updat. 2018, 40, 13-16. [CrossRef] [PubMed]

44. Choi, J.S.; Sansoni, E.R.; Lovin, B.D.; Lindquist, N.R.; Phan, J.; Mayo, L.L.; Ferrarotto, R.; Su, S. Abscopal Effect Following Immunotherapy and Combined Stereotactic Body Radiation Therapy in Recurrent Metastatic Head and Neck Squamous Cell Carcinoma: A Report of Two Cases and Literature Review. Ann. Otol. Rhinol. Laryngol. 2019, 129, 517-522. [CrossRef] [PubMed]

45. Hui, C.; Chau, B.; Gan, G.; Stokes, W.; Karam, S.D.; Amini, A. Overcoming Resistance to Immunotherapy in Head and Neck Cancer Using Radiation: A Review. Front. Oncol. 2021, 11, 2619. [CrossRef] [PubMed]

46. De Oliveira, T.B.; Braun, A.C.; Nicolau, U.R.; Abdallah, E.A.; Alves, V.D.S.; de Jesus, V.H.F.; Calsavara, V.F.; Kowaslki, L.P.; Chinen, L.T.D. Prognostic impact and potential predictive role of baseline circulating tumor cells in locally advanced head and neck squamous cell carcinoma. Oral Oncol. 2021, 121, 105480. [CrossRef] [PubMed]

47. Datta, M.; Laronde, D.; Palcic, B.; Guillaud, M. The role of DNA image cytometry in screening oral potentially malignant lesions using brushings: A systematic review. Oral Oncol. 2019, 96, 51-59. [CrossRef] [PubMed]

48. Datta, M.; Laronde, D.M.; Rosin, M.P.; Zhang, L.; Chan, B.; Guillaud, M. Predicting Progression of Low-Grade Oral Dysplasia Using Brushing-Based DNA Ploidy and Chromatin Organization Analysis. Cancer Prev. Res. 2021, 14, 1111-1118. [CrossRef]

49. Velleuer, E.; Dietrich, R.; Pomjanski, N.; de Santana Almeida Araujo, I.K.; Silva de Araujo, B.E.; Sroka, I.; Biesterfeld, S.; Bocking, A.; Schramm, M. Diagnostic accuracy of brush biopsy-based cytology for the early detection of oral cancer and precursors in Fanconi anemia. Cancer Cytopathol. 2020, 128, 403-413. [CrossRef]

50. Vogel, E.W.; Nivard, M.J. The subtlety of alkylating agents in reactions with biological macromolecules. Mutat. Res. Mol. Mech. Mutagen. 1994, 305, 13-32. [CrossRef]

51. Burtness, B.; Bourhis, J.P.; Vermorken, J.B.; Harrington, K.J.; Cohen, E.E.W. Afatinib versus placebo as adjuvant therapy after chemoradiation in a double-blind, phase III study (LUX-Head \& Neck 2) in patients with primary unresected, clinically intermediate-to-high-risk head and neck cancer: Study protocol for a randomized controlled trial. Trials 2014, 15, 469. [CrossRef]

52. Zech, H.B.; Moeckelmann, N.; Böttcher, A.; Muenscher, A.; Binder, M.; Vettorazzi, E.; Bokemeyer, C.; Schafhausen, P.; Betz, C.S.; Busch, C.-J. Phase III study of nivolumab alone or combined with ipilimumab as immunotherapy versus standard of care in resectable head and neck squamous cell carcinoma. Futur. Oncol. 2020, 16, 3035-3043. [CrossRef] [PubMed]

53. Irshad, R.; Haider, G.; Hashmi, M.; Hassan, A. Efficacy of Gefitinib and Methorexate in Patients with Advanced Stage and Recurrent Head and Neck Cancer. Cureus 2021, 13, e15451. [CrossRef] [PubMed]

54. Vermorken, J.B.; Mesia, R.; Rivera, F.; Remenar, E.; Kawecki, A.; Rottey, S.; Erfan, J.; Zabolotnyy, D.; Kienzer, H.-R.; Cupissol, D.; et al. Platinum-Based Chemotherapy plus Cetuximab in Head and Neck Cancer. N. Engl. J. Med. 2008, 359, 1116-1127. [CrossRef] [PubMed]

55. Specenier, P.; Vermorken, J.B. Optimizing treatments for recurrent or metastatic head and neck squamous cell carcinoma. Expert Rev. Anticancer Ther. 2018, 18, 901-915. [CrossRef] [PubMed]

56. Patil, V.M.; Noronha, V.; Joshi, A.; Abhyankar, A.; Menon, N.; Dhumal, S.; Prabhash, K. Beyond conventional chemotherapy, targeted therapy and immunotherapy in squamous cell cancer of the oral cavity. Oral Oncol. 2020, 105, 104673. [CrossRef] [PubMed]

57. Lau, A.; Yang, W.; Li, K.-Y.; Su, Y.-X. Systemic Therapy in Recurrent or Metastatic Head and Neck Squamous Cell Carcinoma- A Systematic Review and Meta-Analysis. Crit. Rev. Oncol. 2020, 153, 102984. [CrossRef] [PubMed]

58. Musshoff, F. Chromatographic methods for the determination of markers of chronic and acute alcohol consumption. J. Chromatogr. B 2002, 781, 457-480. [CrossRef]

59. IARC Working Group on the Evaluation of Carcinogenic Risks to Humans. Alcohol consumption and ethyl carbamate. IARC Monogr. Eval. Carcinog. Risks Hum. 2010, 96, 3-1383.

60. Sharpe, P.C. Biochemical detection and monitoring of alcohol abuse and abstinence. Ann. Clin. Biochem. Int. J. Lab. Med. 2001, 38, 652-664. [CrossRef]

61. Laposata, M. Assessment of Ethanol Intake: Current Tests and New Assays on the Horizon. Am. J. Clin. Pathol. 1999, 112, 443-450. [CrossRef]

62. Ferraguti, G.; Ciolli, P.; Carito, V.; Battagliese, G.; Mancinelli, R.; Ciafrè, S.; Tirassa, P.; Ciccarelli, R.; Cipriani, A.; Messina, M.P.; et al. Ethylglucuronide in the urine as a marker of alcohol consumption during pregnancy: Comparison with four alcohol screening questionnaires. Toxicol. Lett. 2017, 275, 49-56. [CrossRef]

63. Pragst, F.; Yegles, M. Determination of Fatty Acid Ethyl Esters (FAEE) and Ethyl Glucuronide (EtG) in Hair: A Promising Way for Retrospective Detection of Alcohol Abuse During Pregnancy? Ther. Drug Monit. 2008, 30, 255-263. [CrossRef] [PubMed]

64. Yegles, M.; Labarthe, A.; Auwärter, V.; Hartwig, S.; Vater, H.; Wennig, R.; Pragst, F. Comparison of ethyl glucuronide and fatty acid ethyl ester concentrations in hair of alcoholics, social drinkers and teetotallers. Forensic Sci. Int. 2004, 145, 167-173. [CrossRef] [PubMed]

65. Wurst, F.M.; Alexson, S.; Wolfersdorf, M.; Bechtel, G.; Forster, S.; Alling, C.; Aradóttir, S.; Jachau, K.; Huber, P.; Allen, J.P.; et al. Concentration of fatty acid ethyl esters in hair of alcoholics: Comparison to other biological state markers and self reported-ethanol intake. Alcohol Alcohol. 2004, 39, 33-38. [CrossRef] [PubMed] 
66. Ceci, F.M.; Fiore, M.; Agostinelli, E.; Tahara, T.; Greco, A.; Ralli, M.; Polimeni, A.; Lucarelli, M.; Colletti, R.; Angeloni, A.; et al. Urinary ethyl glucuronide for the assessment of alcohol consumption during pregnancy: Comparison between biochemical data and screening questionnaires. Curr. Med. Chem. 2021, 28, 1. [CrossRef] [PubMed]

67. Budhwani, H.; Dinaj, V.; Jacques-Tiura, A.J.; Pennar, A.L.; Naar, S. Feasibility of Ethyl Glucuronide Nail Testing Biomarker for Alcohol Use Among Youth Living with HIV. J. Adolesc. Health 2021, 69, 346-348. [CrossRef] [PubMed]

68. Cappelle, D.; Neels, H.; De Keukeleire, S.; Fransen, E.; Dom, G.; Vermassen, A.; Covaci, A.; Crunelle, C.L.; van Nuijs, A.L. Ethyl glucuronide in keratinous matrices as biomarker of alcohol use: A correlation study between hair and nails. Forensic Sci. Int. 2017, 279, 187-191. [CrossRef]

69. Fosen, J.T.; Morini, L.; Sempio, C.; Giarratana, N.; Enger, A.; Mørland, J.; Høiseth, G. Ethyl Glucuronide Elimination Kinetics in Fingernails and Comparison to Levels in Hair. Alcohol Alcohol. 2017, 52, 580-586. [CrossRef]

70. Bogstrand, S.T.; Høiseth, G.; Rossow, I.; Normann, P.T.; Ekeberg, Ø. Prevalence of Ethyl Glucuronide and Ethyl Sulphate Among Patients Injured When Driving or at Work. Alcohol Alcohol. 2014, 50, 68-73. [CrossRef]

71. Dengiz, H.; Daglioglu, N.; Goren, I.E. Assessment of recent alcohol consumption by detecting ethyl glucuronide and ethyl sulphate level among traffic accident patients. Traffic Inj. Prev. 2020, 21, 371-374. [CrossRef]

72. Skipper, G.E.; Weinmann, W.; Thierauf, A.; Schaefer, P.; Wiesbeck, G.; Allen, J.P.; Miller, M.; Wurst, F.M. Ethyl glucuronide: A biomarker to identify alcohol use by health professionals recovering from substance use disorders. Alcohol Alcohol. 2004, 39, 445-449. [CrossRef] [PubMed]

73. Liu, H.; Dai, M.; Guan, H.; Gao, X.; Zhou, Y.; Sun, X.; Zhou, J.; Hu, X.; Li, X.; Song, Y.; et al. Preoperative Prognostic Nutritional Index Value is Related to Postoperative Delirium in Elderly Patients After Noncardiac Surgery: A Retrospective Cohort Study. Health Policy 2021, 14, 1-8. [CrossRef]

74. Magnes, T.; Wagner, S.; Kiem, D.; Weiss, L.; Rinnerthaler, G.; Greil, R.; Melchardt, T. Prognostic and Predictive Factors in Advanced Head and Neck Squamous Cell Carcinoma. Int. J. Mol. Sci. 2021, 22, 4981. [CrossRef] [PubMed]

75. Drop, B.; Strycharz-Dudziak, M.; Kliszczewska, E.; Polz-Dacewicz, M. Coinfection with Epstein-Barr Virus (EBV), Human Papilloma Virus (HPV) and Polyoma BK Virus (BKPyV) in Laryngeal, Oropharyngeal and Oral Cavity Cancer. Int. J. Mol. Sci. 2017, 18, 2752. [CrossRef]

76. Pezzuto, F.; Buonaguro, L.; Caponigro, F.; Ionna, F.; Starita, N.; Annunziata, C.; Buonaguro, F.M.; Tornesello, M.L. Update on Head and Neck Cancer: Current Knowledge on Epidemiology, Risk Factors, Molecular Features and Novel Therapies. Oncology 2015, 89, 125-136. [CrossRef] [PubMed]

77. Mahmutović, L.; Bilajac, E.; Hromić-Jahjefendić, A. Meet the Insidious Players: Review of Viral Infections in Head and Neck Cancer Etiology with an Update on Clinical Trials. Microorganisms 2021, 9, 1001. [CrossRef] [PubMed]

78. Rodríguez-Molinero, J.; Migueláñez-Medrán, B.; Puente-Gutiérrez, C.; Delgado-Somolinos, E.; Carreras-Presas, C.M.; FernándezFarhall, J.; López-Sánchez, A. Association between Oral Cancer and Diet: An Update. Nutrients 2021, 13, 1299. [CrossRef] [PubMed]

79. Stokes, W.A.; Molina, E.; McDermott, J.D.; Morgan, R.L.; Bickett, T.; Fakhoury, K.R.; Amini, A.; Karam, S.D. Survival impact of a ngiotensin-converting enzyme inhibitors and angiotensin II receptor antagonists in head and neck cancer. Head Neck 2021, 43, 3255-3275. [CrossRef]

80. Prabhu, A.; Obi, K.O.; Rubenstein, J.H. Systematic review with meta-analysis: Race-specific effects of alcohol and tobacco on the risk of oesophageal squamous cell carcinoma. Aliment. Pharmacol. Ther. 2013, 38, 1145-1155. [CrossRef]

81. Prabhu, A.O.; Obi, K.; Rubenstein, J.H. The Synergistic Effects of Alcohol and Tobacco Consumption on the Risk of Esophageal Squamous Cell Carcinoma: A Meta-Analysis. Am. J. Gastroenterol. 2014, 109, 822-827. [CrossRef]

82. Hashibe, M.; Brennan, P.; Chuang, S.-C.; Boccia, S.; Castellsagué, X.; Chen, C.; Curado, M.P.; Maso, L.D.; Daudt, A.W.; Fabianova, E.; et al. Interaction between Tobacco and Alcohol Use and the Risk of Head and Neck Cancer: Pooled Analysis in the International Head and Neck Cancer Epidemiology Consortium. Cancer Epidemiol. Biomark. Prev. 2009, 18, 541-550. [CrossRef]

83. Talamini, R.; Bosetti, C.; La Vecchia, C.; Maso, L.D.; Levi, F.; Bidoli, E.; Negri, E.; Pasche, C.; Vaccarella, S.; Barzan, L.; et al. Combined effect of tobacco and alcohol on laryngeal cancer risk: A case-control study. Cancer Causes Control. 2002, 13, 957-964. [CrossRef]

84. Toporcov, T.N.; Tavares, G.E.; Rotundo, L.D.B.; Vaccarezza, G.F.; Biazevic, M.G.H.; Brasileiro, R.S.; De Carvalho, M.B.; Junior, P.M.; Kowalski, L.P.; Antunes, J.L.F. Do Tobacco and Alcohol Modify Protective Effects of Diet on Oral Carcinogenesis? Nutr. Cancer 2012, 64, 1182-1189. [CrossRef]

85. Adeoye, J.; Tan, J.Y.; Ip, C.M.; Choi, S.; Thomson, P. “Fact or fiction ?": Oral cavity cancer in nonsmoking, nonalcohol drinking patients as a distinct entity-Scoping review. Head Neck 2021, 43, 3662-3680. [CrossRef]

86. Simon, F.; Schwenk-Zieger, S.; Becker, S.; Unger, K.; Gires, O.; Baumeister, P. Cigarette Smoke Reduces the Efficacy of Cisplatin in Head and Neck Cancer Cells-Role of ABCG2. Anticancer. Res. 2020, 40, 1277-1284. [CrossRef]

87. Crowder, S.L.; Douglas, K.G.; Pepino, M.Y.; Sarma, K.P.; Arthur, A.E. Nutrition impact symptoms and associated outcomes in post-chemoradiotherapy head and neck cancer survivors: A systematic review. J. Cancer Surviv. 2018, 12, 479-494. [CrossRef]

88. Giraldi, L.; Leoncini, E.; Pastorino, R.; Wünsch-Filho, V.; de Carvalho, M.; Lopez, R.; Cadoni, G.; Arzani, D.; Petrelli, L.; Matsuo, K.; et al. Alcohol and cigarette consumption predict mortality in patients with head and neck cancer: A pooled analysis within the International Head and Neck Cancer Epidemiology (INHANCE) Consortium. Ann. Oncol. 2017, 28, 2843-2851. [CrossRef] [PubMed]

89. Yang, Z.; Du, W.; Zhang, X.; Chen, D.; Fang, Q.; He, Y.; Yang, Y.; Li, D.; Fan, J. Nonsmoking and Nondrinking Oral Squamous Cell Carcinoma Patients: A Different Entity. Front. Oncol. 2021, 11, 558320. [CrossRef] [PubMed] 
90. Dediol, E.; Sabol, I.; Virag, M.; Grce, M.; Muller, D.; Manojlović, S. HPV prevalence and p16INKa overexpression in non-smoking non-drinking oral cavity cancer patients. Oral Dis. 2016, 22, 517-522. [CrossRef] [PubMed]

91. Califano, J.; Westra, W.H.; Meininger, G.; Corio, R.; Koch, W.M.; Sidransky, D. Genetic progression and clonal relationship of recurrent premalignant head and neck lesions. Clin. Cancer Res. 2000, 6, 347-352. [PubMed]

92. McCarthy, C.; Fedele, S.; Ottensmeier, C.; Shaw, R. Early-Phase Interventional Trials in Oral Cancer Prevention. Cancers 2021, 13, 3845. [CrossRef]

93. Johnson, D.E.; Burtness, B.; Leemans, C.R.; Lui, V.W.Y.; Bauman, J.E.; Grandis, J.R. Head and neck squamous cell carcinoma. Nat. Rev. Dis. Primers 2020, 6, 92. [CrossRef]

94. Sisk, E.A.; Soltys, S.G.; Zhu, S.; Fisher, S.G.; Carey, T.E.; Bradford, C.R. Human papillomavirus and p53 mutational status as prognostic factors in head and neck carcinoma. Head Neck 2002, 24, 841-849. [CrossRef]

95. Penhallow, J.; Steingrimsdottir, H.; Elamin, F.; Warnakulasuriya, S.; Farzaneh, F.; Johnson, N.; Tavassoli, M. p53 alterations and HPV infections are common in oral SCC: p53 gene mutations correlate with the absence of HPV 16-E6 DNA. Int. J. Oncol. 1998, 12, 59-127. [CrossRef]

96. Hafkamp, H.C.; Speel, E.J.; Haesevoets, A.; Bot, F.J.; Dinjens, W.N.; Ramaekers, F.C.; Hopman, A.H.; Manni, J.J. A subset of head and neck squamous cell carcinomas exhibits integration of HPV 16/18 DNA and overexpression of p16INK4A and p53 in the absence of mutations in p53 exons 5-8. Int. J. Cancer 2003, 107, 394-400. [CrossRef]

97. Bradley, G.; Tremblay, S.; Irish, J.; Macmillan, C.; Baker, G.; Gullane, P.; Benchimol, S. The expression of p53-induced protein with death domain (Pidd) and apoptosis in oral squamous cell carcinoma. Br. J. Cancer 2007, 96, 1425-1432. [CrossRef] [PubMed]

98. Nylander, K.; Dabelsteen, E.; Hall, P.A. The p53 molecule and its prognostic role in squamous cell carcinomas of the head and neck. J. Oral Pathol. Med. 2000, 29, 413-425. [CrossRef]

99. De La Cour, C.D.; Msc, C.D.S.; Belmonte, F.; Syrjänen, S.; Verdoodt, F.; Kjaer, S.K. Prevalence of human papillomavirus in oral epithelial dysplasia: Systematic review and meta-analysis. Head Neck 2020, 42, 2975-2984. [CrossRef] [PubMed]

100. Nankivell, P.; Williams, H.; Webster, K.; Pearson, D.; High, A.; MacLennan, K.; Senguven, B.; McConkey, C.; Rabbitts, P.; Mehanna, H. Investigation of p16INK 4a as a prognostic biomarker in oral epithelial dysplasia. J. Oral Pathol. Med. 2014, 43, 245-249. [CrossRef] [PubMed]

101. Billard-Sandu, C.; Tao, Y.-G.; Sablin, M.-P.; Dumitrescu, G.; Billard, D.; Deutsch, E. CDK4/6 inhibitors in P16/HPV16-negative squamous cell carcinoma of the head and neck. Eur. Arch. Oto-Rhino-Laryngol. 2020, 277, 1273-1280. [CrossRef] [PubMed]

102. Van Caloen, G.; Machiels, J.-P. Potential role of cyclin-dependent kinase $4 / 6$ inhibitors in the treatment of squamous cell carcinoma of the head and neck. Curr. Opin. Oncol. 2019, 31, 122-130. [CrossRef]

103. Deng, Z.; Hasegawa, M.; Aoki, K.; Matayoshi, S.; Kiyuna, A.; Yamashita, Y.; Uehara, T.; Agena, S.; Maeda, H.; Xie, M.; et al. A comprehensive evaluation of human papillomavirus positive status and p16INK4a overexpression as a prognostic biomarker in head and neck squamous cell carcinoma. Int. J. Oncol. 2014, 45, 67-76. [CrossRef] [PubMed]

104. Cancer Genome Atlas Network. Comprehensive genomic characterization of head and neck squamous cell carcinomas. Nature 2015, 517, 576-582. [CrossRef] [PubMed]

105. Jiang, X.; Wang, J.; Deng, X.; Xiong, F.; Zhang, S.; Gong, Z.; Li, X.; Cao, K.; Deng, H.; He, Y.; et al. The role of microenvironment in tumor angiogenesis. J. Exp. Clin. Cancer Res. 2020, 39, 1-19. [CrossRef] [PubMed]

106. Rivera, C. Essentials of oral cancer. Int. J. Clin. Exp. Pathol. 2015, 8, 11884-11894.

107. Singh, N.; Baby, D.; Rajguru, J.P.; Patil, P.B.; Thakkannavar, S.S.; Pujari, V.B. Inflammation and cancer. Ann. Afr. Med. 2019, 18, 121-126. [CrossRef]

108. Yang, E.; Wang, X.; Gong, Z.; Yu, M.; Wu, H.; Zhang, D. Exosome-mediated metabolic reprogramming: The emerging role in tumor microenvironment remodeling and its influence on cancer progression. Signal Transduct. Target. Ther. 2020, 5, 242. [CrossRef] [PubMed]

109. Denaro, N.; Merlano, M.C.; Nigro, C.L. Further Understanding of the Immune Microenvironment in Head and Neck Squamous Cell Carcinoma: Implications for Prognosis. Cancer Manag. Res. 2021, 13, 3973-3980. [CrossRef] [PubMed]

110. Economopoulou, P.; Kotsantis, I.; Psyrri, A. Tumor Microenvironment and Immunotherapy Response in Head and Neck Cancer. Cancers 2020, 12, 3377. [CrossRef]

111. Brizel, D.M.; Sibley, G.S.; Prosnitz, L.R.; Scher, R.L.; Dewhirst, M.W. Tumor hypoxia adversely affects the prognosis of carcinoma of the head and neck. Int. J. Radiat. Oncol. 1997, 38, 285-289. [CrossRef]

112. Ma, B. Virtual microdissection in the molecular subtyping of head and neck squamous carcinoma-A 'Virtual Reality' of the tumor microenvironment? Ann. Oncol. 2019, 30, 8-10. [CrossRef]

113. Chen, Y.P.; Wang, Y.-Q.; Lv, J.-W.; Li, Y.-Q.; Chua, M.; Le, Q.-T.; Lee, N.; Colevas, A.D.; Seiwert, T.; Hayes, D.; et al. Identification and validation of novel microenvironment-based immune molecular subgroups of head and neck squamous cell carcinoma: Implications for immunotherapy. Ann. Oncol. 2019, 30, 68-75. [CrossRef]

114. Krishnamurthy, S.; Dong, Z.; Vodopyanov, D.; Imai, A.; Helman, J.I.; Prince, M.E.; Wicha, M.S.; Nör, J.E. Endothelial Cell-Initiated Signaling Promotes the Survival and Self-Renewal of Cancer Stem Cells. Cancer Res. 2010, 70, 9969-9978. [CrossRef]

115. Pries, R.; Nitsch, S.; Wollenberg, B. Role of cytokines in head and neck squamous cell carcinoma. Expert Rev. Anticancer. Ther. 2006, 6, 1195-1203. [CrossRef]

116. Zhao, Y.; Wang, H.; He, C. Drug resistance of targeted therapy for advanced non-small cell lung cancer harbored EGFR mutation: From mechanism analysis to clinical strategy. J. Cancer Res. Clin. Oncol. 2021, 147, 3653-3664. [CrossRef] [PubMed] 
117. Abdullah, M.N.; Ali, Y.; Hamid, S.A. Insights into the structure and drug design of benzimidazole derivatives targeting the epidermal growth factor receptor (EGFR). Chem. Biol. Drug Des. 2021. [CrossRef] [PubMed]

118. Stefani, C.; Miricescu, D.; Stanescu-Spinu, I.-I.; Nica, R.I.; Greabu, M.; Totan, A.R.; Jinga, M. Growth Factors, PI3K/AKT/mTOR and MAPK Signaling Pathways in Colorectal Cancer Pathogenesis: Where Are We Now? Int. J. Mol. Sci. 2021, $22,10260$. [CrossRef] [PubMed]

119. Montisci, A.; Vietri, M.T.; Palmieri, V.; Sala, S.; Donatelli, F.; Napoli, C. Cardiac Toxicity Associated with Cancer Immunotherapy and Biological Drugs. Cancers 2021, 13, 4797. [CrossRef] [PubMed]

120. Sharma, B.; Singh, V.J.; Chawla, P.A. Epidermal growth factor receptor inhibitors as potential anticancer agents: An update of recent progress. Bioorganic Chem. 2021, 116, 105393. [CrossRef] [PubMed]

121. Pai, S.I.; Westra, W.H. Molecular Pathology of Head and Neck Cancer: Implications for Diagnosis, Prognosis, and Treatment. Annu. Rev. Pathol. Mech. Dis. 2009, 4, 49-70. [CrossRef]

122. Fasano, M.; Della Corte, C.M.; Viscardi, G.; Di Liello, R.; Paragliola, F.; Sparano, F.; Iacovino, M.L.; Castrichino, A.; Doria, F.; Sica, A.; et al. Head and neck cancer: The role of anti-EGFR agents in the era of immunotherapy. Ther. Adv. Med Oncol. 2021, 13. [CrossRef]

123. Kalyankrishna, S.; Grandis, J.R. Epidermal Growth Factor Receptor Biology in Head and Neck Cancer. J. Clin. Oncol. 2006, 24, 2666-2672. [CrossRef]

124. Byeon, H.K.; Ku, M.; Yang, J. Beyond EGFR inhibition: Multilateral combat strategies to stop the progression of head and neck cancer. Exp. Mol. Med. 2019, 51, 1-14. [CrossRef]

125. Thomas, S.; Bhola, N.E.; Zhang, Q.; Contrucci, S.C.; Wentzel, A.L.; Freilino, M.L.; Gooding, W.E.; Siegfried, J.M.; Chan, D.C.; Grandis, J.R. Cross-talk between G Protein-Coupled Receptor and Epidermal Growth Factor Receptor Signaling Pathways Contributes to Growth and Invasion of Head and Neck Squamous Cell Carcinoma. Cancer Res. 2006, 66, 11831-11839. [CrossRef] [PubMed]

126. Lui, V.W.Y.; Thomas, S.M.; Zhang, Q.; Wentzel, A.L.; Siegfried, J.M.; Li, J.Y.; Grandis, J.R. Mitogenic effects of gastrin-releasing peptide in head and neck squamous cancer cells are mediated by activation of the epidermal growth factor receptor. Oncogene 2003, 22, 6183-6193. [CrossRef] [PubMed]

127. Zhang, Q.; Thomas, S.M.; Xi, S.; Smithgall, T.E.; Siegfried, J.M.; Kamens, J.; Gooding, W.E.; Grandis, J.R. Src Family Kinases Mediate Epidermal Growth Factor Receptor Ligand Cleavage, Proliferation, and Invasion of Head and Neck Cancer Cells. Cancer Res. 2004, 64, 6166-6173. [CrossRef] [PubMed]

128. Sahara, S.; Herzog, A.E.; Nör, J.E. Systemic therapies for salivary gland adenoid cystic carcinoma. Am. J. Cancer Res. 2021, 11, 4092-4110.

129. Hartman, G.D.; Lambert-Cheatham, N.A.; Kelley, M.R.; Corson, T.W. Inhibition of APE1/Ref-1 for Neovascular Eye Diseases: From Biology to Therapy. Int. J. Mol. Sci. 2021, 22, 10279. [CrossRef]

130. Akwii, R.G.; Mikelis, C.M. Targeting the Angiopoietin/Tie Pathway: Prospects for Treatment of Retinal and Respiratory Disorders. Drugs 2021, 81, 1731-1749. [CrossRef]

131. Pathak, S.; Sonbol, M.B. Second-Line Treatment Options for Hepatocellular Carcinoma: Current Landscape and Future Direction. J. Hepatocell. Carcinoma 2021, 8, 1147-1158. [CrossRef]

132. Guryanov, I.; Tennikova, T.; Urtti, A. Peptide Inhibitors of Vascular Endothelial Growth Factor A: Current Situation and Perspectives. Pharmaceutics 2021, 13, 1337. [CrossRef]

133. Eso, Y.; Taura, K.; Seno, H. Does immune checkpoint inhibitor exhibit limited efficacy against non-viral hepatocellular carcinoma?: A review of clinical trials. Hepatol. Res. 2021. [CrossRef]

134. Wang, D.; Cheng, J.; Zhang, J.; Zhou, F.; He, X.; Shi, Y.; Tao, Y. The Role of Respiratory Microbiota in Lung Cancer. Int. J. Biol. Sci. 2021, 17, 3646-3658. [CrossRef]

135. Yu, E.-M.; Linville, L.; Rosenthal, M.; Aragon-Ching, J.B. A Contemporary Review of Immune Checkpoint Inhibitors in Advanced Clear Cell Renal Cell Carcinoma. Vaccines 2021, 9, 919. [CrossRef]

136. Almangush, A.; Heikkinen, I.A.; Mäkitie, A.; Coletta, R.D.; Läärä, E.; Leivo, I.; Salo, T. Prognostic biomarkers for oral tongue squamous cell carcinoma: A systematic review and meta-analysis. Br. J. Cancer 2017, 117, 856-866. [CrossRef] [PubMed]

137. Vassilakopoulou, M.; Psyrri, A.; Argiris, A. Targeting angiogenesis in head and neck cancer. Oral Oncol. 2015, 51, 409-415. [CrossRef] [PubMed]

138. Carmeliet, P.; Dor, Y.; Herbert, J.-M.; Fukumura, D.; Brusselmans, K.; Dewerchin, M.; Neeman, M.; Bono, F.; Abramovitch, R.; Maxwell, P.; et al. Role of HIF-1 $\alpha$ in hypoxia-mediated apoptosis, cell proliferation and tumour angiogenesis. Nature 1998, 394, 485-490. [CrossRef] [PubMed]

139. Maxwell, P.H.; Wiesener, M.S.; Chang, G.-W.; Clifford, S.C.; Vaux, E.C.; Cockman, M.E.; Wykoff, C.C.; Pugh, C.W.; Maher, E.R.; Ratcliffe, P.J. The tumour suppressor protein VHL targets hypoxia-inducible factors for oxygen-dependent proteolysis. Nature 1999, 399, 271-275. [CrossRef] [PubMed]

140. Leung, D.W.; Cachianes, G.; Kuang, W.-J.; Goeddel, D.V.; Ferrara, N. Vascular Endothelial Growth Factor Is a Secreted Angiogenic Mitogen. Science 1989, 246, 1306-1309. [CrossRef] [PubMed]

141. Goel, H.L.; Mercurio, A.M. VEGF targets the tumour cell. Nat. Rev. Cancer 2013, 13, 871-882. [CrossRef]

142. Hu, Y.; Ai, L.-S.; Zhou, L.-Q. Prognostic value of FGFR1 expression and amplification in patients with HNSCC: A systematic review and meta-analysis. PLoS ONE 2021, 16, e0251202. [CrossRef] 
143. Dubot, C.; Bernard, V.; Sablin, M.; Vacher, S.; Chemlali, W.; Schnitzler, A.; Pierron, G.; Rais, K.A.; Bessoltane, N.; Jeannot, E.; et al. Comprehensive genomic profiling of head and neck squamous cell carcinoma reveals FGFR1 amplifications and tumour genomic alterations burden as prognostic biomarkers of survival. Eur. J. Cancer 2018, 91, 47-55. [CrossRef]

144. Stanton, M.J.; Dutta, S.; Zhang, H.; Polavaram, N.S.; Leontovich, A.A.; Hönscheid, P.; Sinicrope, F.A.; Tindall, D.J.; Muders, M.H.; Datta, K. Autophagy Control by the VEGF-C/NRP-2 Axis in Cancer and Its Implication for Treatment Resistance. Cancer Res. 2012, 73, 160-171. [CrossRef] [PubMed]

145. Chen, L.; Lin, G.; Chen, K.; Wan, F.; Liang, R.; Sun, Y.; Chen, X.; Zhu, X. VEGF knockdown enhances radiosensitivity of nasopharyngeal carcinoma by inhibiting autophagy through the activation of mTOR pathway. Sci. Rep. 2020, 10, 16328. [CrossRef] [PubMed]

146. Ceccanti, M.; Mancinelli, R.; Tirassa, P.; Laviola, G.; Rossi, S.; Romeo, M.; Fiore, M. Early exposure to ethanol or red wine and long-lasting effects in aged mice. A study on nerve growth factor, brain-derived neurotrophic factor, hepatocyte growth factor, and vascular endothelial growth factor. Neurobiol. Aging 2012, 33, 359-367. [CrossRef]

147. Fiore, M.; Mancinelli, R.; Aloe, L.; Laviola, G.; Sornelli, F.; Vitali, M.; Ceccanti, M. Hepatocyte growth factor, vascular endothelial growth factor, glial cell-derived neurotrophic factor and nerve growth factor are differentially affected by early chronic ethanol or red wine intake. Toxicol. Lett. 2009, 188, 208-213. [CrossRef] [PubMed]

148. Chaldakov, G.N.; Fiore, M.; Tonchev, A.B.; Aloe, L. Neuroadipology: A novel component of neuroendocrinology. Cell Biol. Int. 2010, 34, 1051-1053. [CrossRef]

149. Töre, F.; Tonchev, A.; Fiore, M.; Tuncel, N.; Atanassova, P.; Aloe, L.; Chaldakov, G. From Adipose Tissue Protein Secretion to Adipopharmacology of Disease. Immunol. Endocr. Metab. Agents Med. Chem. 2007, 7, 149-155. [CrossRef]

150. Bonini, S.; Lambiase, A.; Properzi, F.; Bresciani, M.; Sacerdoti, G.; Aloe, L. Nerve growth factor and asthma. Allergy 2002, 57, 13-15. [CrossRef]

151. Ciafrè, S.; Ferraguti, G.; Tirassa, P.; Iannitelli, A.; Ralli, M.; Greco, A.; Chaldakov, G.N.; Rosso, P.; Fico, E.; Messina, M.P.; et al. Nerve growth factor in the psychiatric brain. Riv. Psichiatr. 2020, 55, 4-15.

152. Fiore, M.; Chaldakov, G.N.; Aloe, L. Nerve Growth Factor as a Signaling Molecule for Nerve Cells and also for the NeuroendocrineImmune Systems. Rev. Neurosci. 2009, 20, 133-145. [CrossRef]

153. Ceci, F.M.; Ferraguti, G.; Petrella, C.; Greco, A.; Tirassa, P.; Iannitelli, A.; Ralli, M.; Vitali, M.; Ceccanti, M.; Chaldakov, G.N.; et al. Nerve Growth Factor, Stress and Diseases. Curr. Med. Chem. 2021, 28, 2943-2959. [CrossRef]

154. Chaldakov, G.N.; Stankulov, I.S.; Fiore, M.; Ghenev, P.I.; Aloe, L. Nerve growth factor levels and mast cell distribution in human coronary atherosclerosis. Atherosclerosis 2001, 159, 57-66. [CrossRef]

155. Chaldakov, G.; Fiore, M.; Tonchev, A.; Dimitrov, D.; Pancheva, R.; Rancic, G.; Aloe, L. Homo obesus: A Metabotrophin-Deficient Species. Pharmacology and Nutrition Insight. Curr. Pharm. Des. 2007, 13, 2176-2179. [CrossRef] [PubMed]

156. Chaldakov, G.N.; Fiore, M.; Ghenev, P.I.; Stankulov, I.S.; Aloe, L. Atherosclerotic lesions: Possible interactive involvement of intima, adventitia and associated adipose tissue. Int. Med. J. 2000, 7, 43-49.

157. Angelucci, F.; Piermaria, J.; Gelfo, F.; Shofany, J.; Tramontano, M.; Fiore, M.; Caltagirone, C.; Peppe, A. The effects of motor rehabilitation training on clinical symptoms and serum BDNF levels in Parkinson's disease subjects. Can. J. Physiol. Pharmacol. 2016, 94, 455-461. [CrossRef]

158. Manni, L.; Aloe, L.; Fiore, M. Changes in cognition induced by social isolation in the mouse are restored by electro-acupuncture. Physiol. Behav. 2009, 98, 537-542. [CrossRef]

159. Fiore, M.; Korf, J.; Antonelli, A.; Talamini, L.; Aloe, L. Long-lasting effects of prenatal MAM treatment on water maze performance in rats: Associations with altered brain development and neurotrophin levels. Neurotoxicol. Teratol. 2002, 24, 179-191. [CrossRef]

160. Bersani, G.; Iannitelli, A.; Fiore, M.; Angelucci, F.; Aloe, L. Data and hypotheses on the role of nerve growth factor and other neurotrophins in psychiatric disorders. Med. Hypotheses 2000, 55, 199-207. [CrossRef]

161. Deponti, D.; Buono, R.; Catanzaro, G.; De Palma, C.; Longhi, R.; Meneveri, R.; Bresolin, N.; Bassi, M.T.; Cossu, G.; Clementi, E.; et al. The Low-Affinity Receptor for Neurotrophins p75NTR Plays a Key Role for Satellite Cell Function in Muscle Repair Acting via RhoA. Mol. Biol. Cell 2009, 20, 3620-3627. [CrossRef]

162. Li, X.; Shen, Y.; Di, B.; Li, J.; Geng, J.; Lu, X.; He, Z. Biological and clinical significance of p75NTRexpression in laryngeal squamous epithelia and laryngocarcinoma. Acta Oto-Laryngol. 2011, 132, 314-324. [CrossRef]

163. Dudás, J.; Dietl, W.; Romani, A.; Reinold, S.; Glueckert, R.; Schrott-Fischer, A.; Dejaco, D.; Chacko, L.J.; Tuertscher, R.; Schartinger, V.H.; et al. Nerve Growth Factor (NGF)-Receptor Survival Axis in Head and Neck Squamous Cell Carcinoma. Int. J. Mol. Sci. 2018, 19, 1771. [CrossRef]

164. Ceci, F.M.; Ferraguti, G.; Petrella, C.; Greco, A.; Ralli, M.; Iannitelli, A.; Carito, V.; Tirassa, P.; Chaldakov, G.N.; Messina, M.P.; et al. Nerve Growth Factor in Alcohol Use Disorders. Curr. Neuropharmacol. 2020, 19, 45-60. [CrossRef] [PubMed]

165. Ciafrè, S.; Ferraguti, G.; Greco, A.; Polimeni, A.; Ralli, M.; Ceci, F.M.; Ceccanti, M.; Fiore, M. Alcohol as an early life stressor: Epigenetics, metabolic, neuroendocrine and neurobehavioral implications. Neurosci. Biobehav. Rev. 2020, 118, 654-668. [CrossRef] [PubMed]

166. Hashibe, M.; Boffetta, P.; Zaridze, D.; Shangina, O.; Szeszenia-Dabrowska, N.; Mates, D.; Fabiánová, E.; Rudnai, P.; Brennan, P. Contribution of Tobacco and Alcohol to the High Rates of Squamous Cell Carcinoma of the Supraglottis and Glottis in Central Europe. Am. J. Epidemiol. 2007, 165, 814-820. [CrossRef] [PubMed]

167. Corrao, G. A meta-analysis of alcohol consumption and the risk of 15 diseases. Prev. Med. 2004, 38, 613-619. [CrossRef] 
168. Bagnardi, V.; Blangiardo, M.; La Vecchia, C.; Corrao, G. A meta-analysis of alcohol drinking and cancer risk. Br. J. Cancer 2001, 85, 1700-1705. [CrossRef] [PubMed]

169. Seitz, H.K.; Stickel, F.; Homann, N. Pathogenetic mechanisms of upper aerodigestive tract cancer in alcoholics. Int. J. Cancer 2003, 108, 483-487. [CrossRef]

170. Boccia, S.; Hashibe, M.; Gallì, P.; De Feo, E.; Asakage, T.; Hashimoto, T.; Hiraki, A.; Katoh, T.; Nomura, T.; Yokoyama, A.; et al. Aldehyde Dehydrogenase 2 and Head and Neck Cancer: A Meta-analysis Implementing a Mendelian Randomization Approach. Cancer Epidemiol. Biomark. Prev. 2009, 18, 248-254. [CrossRef]

171. Halliwell, B. Reactive Species and Antioxidants. Redox Biology Is a Fundamental Theme of Aerobic Life. Plant Physiol. 2006, 141, 312-322. [CrossRef]

172. Brennan, P.; Boffetta, P. Mechanistic considerations in the molecular epidemiology of head and neck cancer. IARC Sci. Publ. 2004, 2004, 393-414.

173. Boffetta, P.; Hashibe, M. Alcohol and cancer. Lancet Oncol. 2006, 7, 149-156. [CrossRef]

174. Urashima, M.; Hama, T.; Suda, T.; Suzuki, Y.; Ikegami, M.; Sakanashi, C.; Akutsu, T.; Amagaya, S.; Horiuchi, K.; Imai, Y.; et al. Distinct Effects of Alcohol Consumption and Smoking on Genetic Alterations in Head and Neck Carcinoma. PLoS ONE 2013, 8, e80828. [CrossRef]

175. Chen, Y.-C.; Chen, Y.-W.; Hsu, H.-S.; Tseng, L.-M.; Huang, P.-I.; Lu, K.-H.; Chen, D.-T.; Tai, L.-K.; Yung, M.-C.; Chang, S.-C.; et al. Aldehyde dehydrogenase 1 is a putative marker for cancer stem cells in head and neck squamous cancer. Biochem. Biophys. Res. Commun. 2009, 385, 307-313. [CrossRef]

176. Conway, D.I. Alcohol consumption and the risk for disease. Evidence-Based Dent. 2005, 6, 76-77. [CrossRef] [PubMed]

177. Bhatia, S.; Drake, D.M.; Miller, L.; Wells, P.G. Oxidative stress and DNA damage in the mechanism of fetal alcohol spectrum disorders. Birth Defects Res. 2019, 111, 714-748. [CrossRef] [PubMed]

178. Lee, C.-H.; Wu, D.-C.; Wu, I.-C.; Goan, Y.-G.; Lee, J.-M.; Chou, S.-H.; Chan, T.-F.; Huang, H.-L.; Hung, Y.-H.; Huang, M.-C.; et al. Genetic modulation of ADH1B and ALDH2 polymorphisms with regard to alcohol and tobacco consumption for younger aged esophageal squamous cell carcinoma diagnosis. Int. J. Cancer 2009, 125, 1134-1142. [CrossRef] [PubMed]

179. Kanda, J.; Matsuo, K.; Suzuki, T.; Kawase, T.; Hiraki, A.; Watanabe, M.; Mizuno, N.; Sawaki, A.; Yamao, K.; Tajima, K.; et al. Impact of alcohol consumption with polymorphisms in alcohol-metabolizing enzymes on pancreatic cancer risk in Japanese. Cancer Sci. 2009, 100, 296-302. [CrossRef]

180. Oze, I.; Matsuo, K.; Suzuki, T.; Kawase, T.; Watanabe, M.; Hiraki, A.; Ito, H.; Hosono, S.; Ozawa, T.; Hatooka, S.; et al. Impact of Multiple Alcohol Dehydrogenase Gene Polymorphisms on Risk of Upper Aerodigestive Tract Cancers in a Japanese Population. Cancer Epidemiol. Biomark. Prev. 2009, 18, 3097-3102. [CrossRef] [PubMed]

181. Druesne-Pecollo, N.; Tehard, B.; Mallet, Y.; Gerber, M.; Norat, T.; Hercberg, S.; Latino-Martel, P. Alcohol and genetic polymorphisms: Effect on risk of alcohol-related cancer. Lancet Oncol. 2009, 10, 173-180. [CrossRef]

182. Yoshida, A.; Ikawa, M.; Hsu, L.; Tani, K. Molecular abnormality and cDNA cloning of human aldehyde dehydrogenases. Alcohol 1985, 2, 103-106. [CrossRef]

183. Yokoyama, A.; Yokoyama, T.; Kimura, M.; Matsushita, S.; Yokoyama, M. Combinations of alcohol-induced flushing with genetic polymorphisms of alcohol and aldehyde dehydrogenases and the risk of alcohol dependence in Japanese men and women. PLoS ONE 2021, 16, e0255276. [CrossRef] [PubMed]

184. Higuchi, S.; Matsushita, S.; Murayama, M.; Takagi, S.; Hayashida, M. Alcohol and aldehyde dehydrogenase polymorphisms and the risk for alcoholism. Am. J. Psychiatry 1995, 152, 1219-1221. [CrossRef] [PubMed]

185. Brocardo, P.S.; Gil-Mohapel, J.; Christie, B.R. The role of oxidative stress in fetal alcohol spectrum disorders. Brain Res. Rev. 2011, 67, 209-225. [CrossRef] [PubMed]

186. Miller-Pinsler, L.; Wells, P.G. Deficient DNA repair exacerbates ethanol-initiated DNA oxidation and embryopathies in ogg1 knockout mice: Gender risk and protection by a free radical spin trapping agent. Arch. Toxicol. 2014, 90, 415-425. [CrossRef] [PubMed]

187. Nair, U.; Bartsch, H.; Nair, J. Lipid peroxidation-induced DNA damage in cancer-prone inflammatory diseases: A review of published adduct types and levels in humans. Free. Radic. Biol. Med. 2007, 43, 1109-1120. [CrossRef]

188. De Bont, R. Endogenous DNA damage in humans: A review of quantitative data. Mutagenesis 2004, 19, 169-185. [CrossRef]

189. Ekström, G.; Ingelman-Sundberg, M. Rat liver microsomal NADPH-supported oxidase activity and lipid peroxidation dependent on ethanol-inducible cytochrome P-450 (P-450IIE1). Biochem. Pharmacol. 1989, 38, 1313-1319. [CrossRef]

190. Chu, J.; Tong, M.; De La Monte, S.M. Chronic ethanol exposure causes mitochondrial dysfunction and oxidative stress in immature central nervous system neurons. Acta Neuropathol. 2007, 113, 659-673. [CrossRef] [PubMed]

191. Wells, P.G.; Bhatia, S.; Drake, D.M.; Miller-Pinsler, L. Fetal oxidative stress mechanisms of neurodevelopmental deficits and exacerbation by ethanol and methamphetamine. Birth Defects Res. Part C Embryo Today Rev. 2016, 108, 108-130. [CrossRef] [PubMed]

192. Vermot, A.; Petit-Härtlein, I.; Smith, S.; Fieschi, F. NADPH Oxidases (NOX): An Overview from Discovery, Molecular Mechanisms to Physiology and Pathology. Antioxidants 2021, 10, 890. [CrossRef]

193. Si, J.; Behar, J.; Wands, J.; Beer, D.G.; Lambeth, D.; Chin, Y.E.; Cao, W. STAT5 mediates PAF-induced NADPH oxidase NOX5-S expression in Barrett's esophageal adenocarcinoma cells. Am. J. Physiol. Liver Physiol. 2008, 294, G174-G183. [CrossRef] 
194. Heaton, M.B.; Madorsky, I.; Paiva, M.; Siler-Marsiglio, K.I. Vitamin E amelioration of ethanol neurotoxicity involves modulation of apoptotis-related protein levels in neonatal rat cerebellar granule cells. Dev. Brain Res. 2004, 150, 117-124. [CrossRef]

195. Shirpoor, A.; Salami, S.; Minassian, S.; Yegiazarian, M.; Khadem-Ansari, M.H. Protective Effect of Vitamin E Against EthanolInduced Hyperhomocysteinemia, DNA Damage, and Atrophy in the Developing Male Rat Brain. Alcohol. Clin. Exp. Res. 2009, 33, 1181-1186. [CrossRef]

196. Marino, M.D.; Aksenov, M.Y.; Kelly, S.J. Vitamin E protects against alcohol-induced cell loss and oxidative stress in the neonatal rat hippocampus. Int. J. Dev. Neurosci. 2004, 22, 363-377. [CrossRef] [PubMed]

197. Wentzel, P.; Rydberg, U.; Eriksson, U.J. Antioxidative Treatment Diminishes Ethanol-Induced Congenital Malformations in the Rat. Alcohol. Clin. Exp. Res. 2006, 30, 1752-1760. [CrossRef] [PubMed]

198. Petrella, C.; Carito, V.; Carere, C.; Ferraguti, G.; Ciafrè, S.; Natella, F.; Bello, C.; Greco, A.; Ralli, M.; Mancinelli, R.; et al. Oxidative stress inhibition by resveratrol in alcohol-dependent mice. Nutrion 2020, 79-80, 110783. [CrossRef]

199. Carito, V.; Ceccanti, M.; Cestari, V.; Natella, F.; Bello, C.; Coccurello, R.; Mancinelli, R.; Fiore, M. Olive polyphenol effects in a mouse model of chronic ethanol addiction. Nutrion 2017, 33, 65-69. [CrossRef] [PubMed]

200. Cano, M.; Ayala, A.; Murillo, M.; Carreras, O. Protective effect of folic acid against oxidative stress produced in 21-day postpartum rats by maternal-ethanol chronic consumption during pregnancy and lactation period. Free. Radic. Res. 2001, 34, 1-8. [CrossRef]

201. Chen, S.-Y.; Dehart, D.B.; Sulik, K.K. Protection from ethanol-induced limb malformations by the superoxide dismutase/catalase mimetic, EUK-134. FASEB J. 2004, 18, 1234-1236. [CrossRef]

202. Lee, S.-R.; Kim, M.-R.; Yon, J.-M.; Baek, I.-J.; Park, C.G.; Lee, B.J.; Yun, Y.W.; Nam, S.-Y. Black ginseng inhibits ethanol-induced teratogenesis in cultured mouse embryos through its effects on antioxidant activity. Toxicol. Vitr. 2009, 23, 47-52. [CrossRef]

203. Mitchell, J.; Paiva, M.; Heaton, M.B. The Antioxidants Vitamin E and $\beta$-Carotene Protect Against Ethanol-Induced Neurotoxicity in Embryonic Rat Hippocampal Cultures. Alcohol 1999, 17, 163-168. [CrossRef]

204. Peng, Y.; Kwok, K.; Yang, P.-H.; Ng, S.S.; Liu, J.; Wong, O.; He, M.-L.; Kung, H.-F.; Lin, M.C. Ascorbic acid inhibits ROS production, NF- $\mathrm{kB}$ activation and prevents ethanol-induced growth retardation and microencephaly. Neuropharmacology 2005, 48, 426-434. [CrossRef] [PubMed]

205. Siler-Marsiglio, K.I.; Shaw, G.; Heaton, M.B. Pycnogenol®and vitamin E inhibit ethanol-induced apoptosis in rat cerebellar granule cells. J. Neurobiol. 2004, 59, 261-271. [CrossRef] [PubMed]

206. Miller, L.; Shapiro, A.M.; Cheng, J.; Wells, P.G. The free radical spin trapping agent phenylbutylnitrone reduces fetal brain DNA oxidation and postnatal cognitive deficits caused by in utero exposure to a non-structurally teratogenic dose of ethanol: A role for oxidative stress. Free. Radic. Biol. Med. 2013, 60, 223-232. [CrossRef]

207. Miller-Pinsler, L.; Wells, P.G. Embryonic catalase protects against ethanol embryopathies in acatalasemic mice and transgenic human catalase-expressing mice in embryo culture. Toxicol. Appl. Pharmacol. 2015, 287, 232-239. [CrossRef] [PubMed]

208. Zhang, Y.; Wang, X.; Li, H.; Ni, C.; Du, Z.; Yan, F. Human oral microbiota and its modulation for oral health. Biomed. Pharmacother. 2018, 99, 883-893. [CrossRef] [PubMed]

209. Sun, J.; Tang, Q.; Yu, S.; Xie, M.; Xie, Y.; Chen, G.; Chen, L. Role of the oral microbiota in cancer evolution and progression. Cancer Med. 2020, 9, 6306-6321. [CrossRef] [PubMed]

210. Zhang, L.; Liu, Y.; Zheng, H.J.; Zhang, C.P. The Oral Microbiota May Have Influence on Oral Cancer. Front. Cell. Infect. Microbiol. 2020, 9, 476. [CrossRef]

211. Zhao, H.; Chu, M.; Huang, Z.; Yang, X.; Ran, S.; Hu, B.; Zhang, C.; Liang, J. Variations in oral microbiota associated with oral cancer. Sci. Rep. 2017, 7, 11773. [CrossRef]

212. Le Bars, P.; Matamoros, S.; Montassier, E.; Le Vacon, F.; Potel, G.; Soueidan, A.; Jordana, F.; De La Cochetière, M.-F. The oral cavity microbiota: Between health, oral disease, and cancers of the aerodigestive tract. Can. J. Microbiol. 2017, 63, 475-492. [CrossRef] [PubMed]

213. Nagy, K.; Sonkodi, I.; Szöke, I.; Nagy, E.; Newman, H. The microflora associated with human oral carcinomas. Oral Oncol. 1998, 34, 304-308. [CrossRef]

214. Healy, C.; Moran, G.P. The microbiome and oral cancer: More questions than answers. Oral Oncol. 2019, 89, 30-33. [CrossRef] [PubMed]

215. Fan, X.; Peters, B.A.; Jacobs, E.J.; Gapstur, S.M.; Purdue, M.P.; Freedman, N.D.; Alekseyenko, A.V.; Wu, J.; Yang, L.; Pei, Z.; et al. Drinking alcohol is associated with variation in the human oral microbiome in a large study of American adults. Microbiome 2018, 6, 59. [CrossRef] [PubMed]

216. Koll-Klais, P.; Mandar, R.; Leibur, E.; Marcotte, H.; Hammarstrom, L.; Mikelsaar, M. Oral lactobacilli in chronic periodontitis and periodontal health: Species composition and antimicrobial activity. Oral Microbiol. Immunol. 2005, 20, 354-361. [CrossRef]

217. Twetman, S.; Derawi, B.; Keller, M.K.; Ekstrand, K.; Yucel-Lindberg, T.; Stecksén-Blicks, C. Short-term effect of chewing gums containing probioticLactobacillus reuterion the levels of inflammatory mediators in gingival crevicular fluid. Acta Odontol. Scand. 2009, 67, 19-24. [CrossRef] [PubMed]

218. Salaspuro, M. Local Acetaldehyde: Its Key Role in Alcohol-Related Oropharyngeal Cancer. Visc. Med. 2020, 36, 167-174. [CrossRef]

219. Moritani, K.; Takeshita, T.; Shibata, Y.; Ninomiya, T.; Kiyohara, Y.; Yamashita, Y. Acetaldehyde production by major oral microbes. Oral Dis. 2015, 21, 748-754. [CrossRef] 
220. Pikkarainen, P.H.; Baraona, E.; Jauhonen, P.; Seitz, H.K.; Lieber, C.S. Contribution of oropharynx microflora and of lung microsomes to acetaldehyde in expired air after alcohol ingestion. J. Lab. Clin. Med. 1981, 97, 631-636.

221. Miyakawa, H.; Baraona, E.; Chang, J.C.; Lesser, M.D.; Lieber, C.S. Oxidation of Ethanol to Acetaldehyde by Bronchopulmonary Washings: Role of Bacteria. Alcohol. Clin. Exp. Res. 1986, 10, 517-520. [CrossRef]

222. Muto, M.; Hitomi, Y.; Ohtsu, A.; Shimada, H.; Kashiwase, Y.; Sasaki, H.; Yoshida, S.; Esumi, H. Acetaldehyde production by non-pathogenic Neisseria in human oral microflora: Implications for carcinogenesis in upper aerodigestive tract. Int. J. Cancer 2000, 88, 342-350. [CrossRef]

223. Yokoyama, S.; Takeuchi, K.; Shibata, Y.; Kageyama, S.; Matsumi, R.; Takeshita, T.; Yamashita, Y. Characterization of oral microbiota and acetaldehyde production. J. Oral Microbiol. 2018, 10, 1492316. [CrossRef]

224. Shelburne, S.A.; Sahasrabhojane, P.; Saldaña, M.; Yao, H.; Su, X.; Horstmann, N.; Thompson, E.; Flores, A.R. Streptococcus mitisStrains Causing Severe Clinical Disease in Cancer Patients. Emerg. Infect. Dis. 2014, 20, 762-771. [CrossRef]

225. Yang, C.-Y.; Yeh, Y.-M.; Yu, H.-Y.; Chin, C.-Y.; Hsu, C.-W.; Liu, H.; Huang, P.-J.; Hu, S.-N.; Liao, C.-T.; Chang, K.-P.; et al. Oral Microbiota Community Dynamics Associated with Oral Squamous Cell Carcinoma Staging. Front. Microbiol. $2018,9,862$. [CrossRef] [PubMed]

226. Cirauqui, M.L.G.; Nieminen, M.; Frazer, L.N.; Aguirre-Urizar, J.M.; Moragues, M.-D.; Rautemaa, R. Production of carcinogenic acetaldehyde byCandida albicansfrom patients with potentially malignant oral mucosal disorders. J. Oral Pathol. Med. 2012, 42, 243-249. [CrossRef]

227. Bakri, M.M.; Rich, A.; Cannon, R.; Holmes, A. In vitroexpression ofCandida albicansalcohol dehydrogenase genes involved in acetaldehyde metabolism. Mol. Oral Microbiol. 2014, 30, 27-38. [CrossRef]

228. Song, Y.; Li, S.; Zhao, Y.; Zhang, Y.; Lv, Y.; Jiang, Y.; Wang, Y.; Li, D.; Zhang, H. ADH1 promotes Candida albicans pathogenicity by stimulating oxidative phosphorylation. Int. J. Med. Microbiol. 2019, 309, 151330. [CrossRef]

229. Marttila, E.; Bowyer, P.; Sanglard, D.; Uittamo, J.; Kaihovaara, P.; Salaspuro, M.; Richardson, M.; Rautemaa, R. Fermentative 2-carbon metabolism produces carcinogenic levels of acetaldehyde inCandida albicans. Mol. Oral Microbiol. 2013, 28, $281-291$. [CrossRef]

230. Nieminen, M.T.; Uittamo, J.; Salaspuro, M.; Rautemaa, R. Acetaldehyde production from ethanol and glucose by nonCandidaalbicans yeasts in vitro. Oral Oncol. 2009, 45, e245-e248. [CrossRef]

231. Messina, M.P.; D’Angelo, A.; Giovagnoli, R.; Napolitano, M.; Petrella, C.; Ralli, M.; Greco, A.; Ricchi, A.; Neri, I.; Fiore, M.; et al. Cancer screenings among sexual and gender minorities by midwives' point of view. Minerva Obstet. Gynecol. 2021. [CrossRef] [PubMed]

232. Balbo, S.; Brooks, P.J. Implications of Acetaldehyde-Derived DNA Adducts for Understanding Alcohol-Related Carcinogenesis. Adv. Exp. Med. Biol. 2015, 815, 71-88. [CrossRef]

233. Brooks, P.J.; Zakhari, S. Acetaldehyde and the genome: Beyond nuclear DNA adducts and carcinogenesis. Environ. Mol. Mutagen. 2014, 55, 77-91. [CrossRef]

234. Sapkota, M.; Wyatt, T.A. Alcohol, Aldehydes, Adducts and Airways. Biomolecules 2015, 5, 2987-3008. [CrossRef]

235. Wiencke, J.K. DNA adduct burden and tobacco carcinogenesis. Oncogene 2002, 21, 7376-7391. [CrossRef]

236. Jethwa, A.R.; Khariwala, S.S. Tobacco-related carcinogenesis in head and neck cancer. Cancer Metastasis Rev. 2017, 36, 411-423. [CrossRef]

237. Munnia, A.; Giese, R.W.; Polvani, S.; Galli, A.; Cellai, F.; Peluso, M.E. Bulky DNA Adducts, Tobacco Smoking, Genetic Susceptibility, and Lung Cancer Risk. Adv. Appl. Microbiol. 2017, 81, 231-277. [CrossRef]

238. Khariwala, S.S.; Hatsukami, D.; Hecht, S.S. Tobacco carcinogen metabolites and DNA adducts as biomarkers in Head and Neck cancer: Potential screening tools and prognostic indicators. Head Neck 2011, 34, 441-447. [CrossRef]

239. Balbo, S.; Meng, L.; Bliss, R.L.; Jensen, J.A.; Hatsukami, D.K.; Hecht, S. Kinetics of DNA Adduct Formation in the Oral Cavity after Drinking Alcohol. Cancer Epidemiol. Biomark. Prev. 2012, 21, 601-608. [CrossRef] [PubMed]

240. Brooks, P.J.; Theruvathu, J.A. DNA adducts from acetaldehyde: Implications for alcohol-related carcinogenesis. Alcohol 2005, 35, 187-193. [CrossRef] [PubMed]

241. Yu, H.-S.; Oyama, T.; Isse, T.; Kitagawa, K.; Pham, T.-T.-P.; Tanaka, M.; Kawamoto, T. Formation of acetaldehyde-derived DNA adducts due to alcohol exposure. Chem. Biol. Interact. 2010, 188, 367-375. [CrossRef] [PubMed]

242. Matsuda, T.; Matsumoto, A.; Uchida, M.; Kanaly, R.A.; Misaki, K.; Shibutani, S.; Kawamoto, T.; Kitagawa, K.; Nakayama, K.I.; Tomokuni, K.; et al. Increased formation of hepatic N2-ethylidene-2'-deoxyguanosine DNA adducts in aldehyde dehydrogenase 2-knockout mice treated with ethanol. Carcinogenesis 2007, 28, 2363-2366. [CrossRef]

243. Brooks, P.J.; Enoch, M.-A.; Goldman, D.; Li, T.-K.; Yokoyama, A. The Alcohol Flushing Response: An Unrecognized Risk Factor for Esophageal Cancer from Alcohol Consumption. PLoS Med. 2009, 6, e1000050. [CrossRef] [PubMed]

244. Espina, N.; Lima, V.; Lieber, C.S.; Garro, A.J. In vitro and in vivo inhibitory effect of ethanol and acetaldehyde on O6methylguanine transferase. Carcinogenesis 1988, 9, 761-766. [CrossRef] [PubMed]

245. Seitz, H.K.; Mueller, S. Alcohol and Cancer: An Overview with Special Emphasis on the Role of Acetaldehyde and Cytochrome P450 2E1. Adv. Exp. Med. Biol. 2015, 815, 59-70. [CrossRef] [PubMed]

246. Heymann, H.M.; Gardner, A.M.; Gross, E.R. Aldehyde-Induced DNA and Protein Adducts as Biomarker Tools for Alcohol Use Disorder. Trends Mol. Med. 2018, 24, 144-155. [CrossRef] [PubMed] 
247. Varela-Rey, M.; Woodhoo, A.; Martinez-Chantar, M.L.; Mato, J.M.; Lu, S.C. Alcohol, DNA methylation, and cancer. Alcohol Res. Curr. Rev. 2012, 35, 25-35.

248. Dumitrescu, R.G. Alcohol-Induced Epigenetic Changes in Cancer. Springer Protocols Handbooks 2018, 1856, 157-172. [CrossRef]

249. Lewandowska, A.M.; Rudzki, M.; Rudzki, S.; Lewandowski, T.; Laskowska, B. Environmental risk factors for cancer-Review paper. Ann. Agric. Environ. Med. 2019, 26, 1-7. [CrossRef]

250. Bakhtiar, S.M.; Ali, A.; Barh, D. Epigenetics in Head and Neck Cancer. Springer Protocols Handbooks 2015, 1238, 751-769. [CrossRef]

251. Foy, J.-P.; Pickering, C.; Papadimitrakopoulou, V.A.; Jelinek, J.; Lin, S.H.; William, W.N.; Frederick, M.J.; Wang, J.; Lang, W.; Feng, L.; et al. New DNA Methylation Markers and Global DNA Hypomethylation Are Associated with Oral Cancer Development. Cancer Prev. Res. 2015, 8, 1027-1035. [CrossRef]

252. Basu, B.; Chakraborty, J.; Chandra, A.; Katarkar, A.; Baldevbhai, J.R.K.; Chowdhury, D.D.; Ray, J.G.; Chaudhuri, K.; Chatterjee, R. Genome-wide DNA methylation profile identified a unique set of differentially methylated immune genes in oral squamous cell carcinoma patients in India. Clin. Epigenet. 2017, 9, 13. [CrossRef]

253. Towle, R.; Truong, D.; Hogg, K.; Robinson, W.P.; Poh, C.F.; Garnis, C. Global analysis of DNA methylation changes during progression of oral cancer. Oral Oncol. 2013, 49, 1033-1042. [CrossRef]

254. Ha, P.K.; Califano, A.J. Promoter methylation and inactivation of tumour-suppressor genes in oral squamous-cell carcinoma Lancet Oncol. 2006, 7, 77-82. [CrossRef]

255. Viswanathan, M.; Tsuchida, N.; Shanmugam, G. Promoter hypermethylation profile of tumor-associated genes p16, p15, hMLH1, MGMT and E-cadherin in oral squamous cell carcinoma. Int. J. Cancer 2003, 105, 41-46. [CrossRef]

256. Su, P.-F.; Huang, W.-L.; Wu, H.-T.; Wu, C.-H.; Liu, T.-Y.; Kao, S.-Y. p16INK4A promoter hypermethylation is associated with invasiveness and prognosis of oral squamous cell carcinoma in an age-dependent manner. Oral Oncol. 2010, 46, 734-739. [CrossRef] [PubMed]

257. Kato, K.; Hara, A.; Kuno, T.; Mori, H.; Yamashita, T.; Toida, M.; Shibata, T. Aberrant promoter hypermethylation of p16 and MGMT genes in oral squamous cell carcinomas and the surrounding normal mucosa. J. Cancer Res. Clin. Oncol. 2006, 132, 735-743. [CrossRef] [PubMed]

258. Ciafrè, S.; Carito, V.; Ferraguti, G.; Greco, A.; Chaldakov, G.N.; Fiore, M.; Ceccanti, M. How alcohol drinking affects our genes: An epigenetic point of view. Biochem. Cell Biol. 2019, 97, 345-356. [CrossRef] [PubMed]

259. Starkman, B.G.; Sakharkar, A.J.; Pandey, S.C. Epigenetics-Beyond the Genome in Alcoholism. Alcohol Res. Curr. Rev. 2012, 34, 293-305.

260. Fan, C.-Y. Epigenetic alterations in head and neck cancer: Prevalence, clinical significance, and implications. Curr. Oncol. Rep. 2004, 6, 152-161. [CrossRef]

261. Jones, P.A.; Laird, P.W. Cancer-epigenetics comes of age. Nat. Genet. 1999, 21, 163-167. [CrossRef]

262. Smith, I.M.; Mydlarz, W.K.; Mithani, S.K.; Califano, J.A. DNA global hypomethylation in squamous cell head and neck cancer associated with smoking, alcohol consumption and stage. Int. J. Cancer 2007, 121, 1724-1728. [CrossRef]

263. Richards, K.L.; Zhang, B.; Baggerly, K.A.; Colella, S.; Lang, J.C.; Schuller, D.E.; Krahe, R. Genome-Wide Hypomethylation in Head and Neck Cancer Is More Pronounced in HPV-Negative Tumors and Is Associated with Genomic Instability. PLoS ONE 2009, 4, e4941. [CrossRef] [PubMed]

264. Poage, G.M.; Christensen, B.C.; Houseman, E.A.; McClean, M.D.; Wiencke, J.K.; Posner, M.R.; Clark, J.R.; Nelson, H.H.; Marsit, C.J.; Kelsey, K.T. Genetic and Epigenetic Somatic Alterations in Head and Neck Squamous Cell Carcinomas Are Globally Coordinated but Not Locally Targeted. PLoS ONE 2010, 5, e9651. [CrossRef] [PubMed]

265. Marsit, C.J.; Christensen, B.C.; Houseman, E.A.; Karagas, M.R.; Wrensch, M.R.; Yeh, R.-F.; Nelson, H.H.; Wiemels, J.L.; Zheng, S.; Posner, M.R.; et al. Epigenetic profiling reveals etiologically distinct patterns of DNA methylation in head and neck squamous cell carcinoma. Carcinogenesis 2009, 30, 416-422. [CrossRef] [PubMed]

266. Gagliardi, M.; Strazzullo, M.; Matarazzo, M.R. DNMT3B Functions: Novel Insights from Human Disease. Front. Cell Dev. Biol. 2018, 6, 140. [CrossRef]

267. Liu, Z.; Wang, L.; Wang, L.-E.; Sturgis, E.M.; Wei, Q. Polymorphisms of the DNMT3B gene and risk of squamous cell carcinoma of the head and neck: A case-control study. Cancer Lett. 2008, 268, 158-165. [CrossRef]

268. Youssef, E.M.; Lotan, D.; Issa, J.-P.; Wakasa, K.; Fan, Y.-H.; Mao, L.; Hassan, K.; Feng, L.; Lee, J.J.; Lippman, S.M.; et al Hypermethylation of the Retinoic Acid Receptor- $\beta 2$ Gene in Head and Neck Carcinogenesis. Clin. Cancer Res. 2004, 10, 1733-1742. [CrossRef]

269. Sailasree, R.; Abhilash, A.; Sathyan, K.; Nalinakumari, K.; Thomas, S.; Kannan, S. Differential Roles of p16INK4A and p14ARF Genes in Prognosis of Oral Carcinoma. Cancer Epidemiol. Biomark. Prev. 2008, 17, 414-420. [CrossRef]

270. Irimie, A.I.; Ciocan, C.; Gulei, D.; Mehterov, N.; Atanasov, A.G.; Dudea, D.; Berindan-Neagoe, I. Current Insights into Oral Cancer Epigenetics. Int. J. Mol. Sci. 2018, 19, 670. [CrossRef]

271. Shaw, R.J.; Liloglou, T.; Rogers, S.N.; Brown, J.S.; Vaughan, E.D.; Lowe, D.; Field, J.; Risk, J.M. Promoter methylation of P16, RAR $\beta$, E-cadherin, cyclin A1 and cytoglobin in oral cancer: Quantitative evaluation using pyrosequencing. Br. J. Cancer 2006, 94, 561-568. [CrossRef]

272. Gasche, J.A.; Hoffmann, J.; Boland, C.R.; Goel, A. Interleukin-6 promotes tumorigenesis by altering DNA methylation in oral cancer cells. Int. J. Cancer 2010, 129, 1053-1063. [CrossRef] 
273. Carito, V.; Venditti, A.; Bianco, A.; Ceccanti, M.; Serrilli, A.M.; Chaldakov, G.; Tarani, L.; De Nicolò, S.; Fiore, M. Effects of olive leaf polyphenols on male mouse brain NGF, BDNF and their receptors TrkA, TrkB and p75. Nat. Prod. Res. 2014, 28, 1970-1984. [CrossRef]

274. Carito, V.; Ceccanti, M.; Tarani, L.; Ferraguti, G.; Chaldakov, G.N.; Fiore, M. Neurotrophins'; Modulation by Olive Polyphenols. Curr. Med. Chem. 2016, 23, 3189-3197. [CrossRef]

275. Chianese, R.; Coccurello, R.; Viggiano, A.; Scafuro, M.; Fiore, M.; Coppola, G.; Operto, F.F.; Fasano, S.; Laye, S.; Pierantoni, R.; et al. Impact of Dietary Fats on Brain Functions. Curr. Neuropharmacol. 2018, 16, 1059-1085. [CrossRef] [PubMed]

276. Fiore, M.; Messina, M.P.; Petrella, C.; D’Angelo, A.; Greco, A.; Ralli, M.; Ferraguti, G.; Tarani, L.; Vitali, M.; Ceccanti, M. Antioxidant properties of plant polyphenols in the counteraction of alcohol-abuse induced damage: Impact on the Mediterranean diet. J. Funct. Foods 2020, 71, 104012. [CrossRef]

277. Ceccanti, M.; De Nicolò, S.; Mancinelli, R.; Chaldakov, G.; Carito, V.; Ceccanti, M.; Laviola, G.; Tirassa, P.; Fiore, M. NGF and BDNF long-term variations in the thyroid, testis and adrenal glands of a mouse model of fetal alcohol spectrum disorders. Ann. dell'Istituto Super. Sanità 2013, 49, 383-390. [PubMed]

278. Solfrizzi, V.; Capurso, C.; D’Introno, A.; Colacicco, A.M.; Santamato, A.; Ranieri, M.; Fiore, P.; Capurso, A.; Panza, F. Lifestylerelated factors in predementia and dementia syndromes. Expert Rev. Neurother. 2008, 8, 133-158. [CrossRef] [PubMed]

279. Carito, M.C.V.; Ceccanti, M.; Vitali, M.; Iannuzzi, S.; Tarani, L.; De Nicolo, S.; Ciafre, S.; Tirassa, P.; Capriglione, I.; Coriale, G.; et al. Serum BDNF and NGF Modulation by Olive Polyphenols in Alcoholics during Withdrawal. J. Alcohol. Drug Depend. 2015, 3. [CrossRef]

280. Manach, C.; Scalbert, A.; Morand, C.; Rémésy, C.; Jiménez, L. Polyphenols: Food sources and bioavailability. Am. J. Clin. Nutr. 2004, 79, 727-747. [CrossRef]

281. Manach, C.; Williamson, G.; Morand, C.; Scalbert, A.; Rémésy, C. Bioavailability and bioefficacy of polyphenols in humans. I. Review of 97 bioavailability studies. Am. J. Clin. Nutr. 2005, 81, 230S-242S. [CrossRef]

282. Petrella, C.; Ferraguti, G.; Tarani, L.; Chaldakov, G.N.; Ceccanti, M.; Greco, A.; Ralli, M.; Fiore, M. Olive polyphenols and chronic alcohol protection. Olives Olive Oil Health Dis. Prev. 2021, 471-478. [CrossRef]

283. Petrella, C.; Di Certo, M.G.; Gabanella, F.; Barbato, C.; Ceci, F.M.; Greco, A.; Ralli, M.; Polimeni, A.; Angeloni, A.; Severini, C.; et al. Mediterranean Diet, Brain and Muscle: Olive Polyphenols and Resveratrol Protection in Neurodegenerative and Neuromuscular Disorders. Curr. Med. Chem. 2021, 28, 1. [CrossRef]

284. Bosco, S.M.D. Beneficios polifenoles hoja de olivo (olea europaea 1) para la salud. Nutrición Hospitalaria 2015, 31, 1427-1433. [CrossRef]

285. Román, G.C.; Jackson, R.E.; Gadhia, R.; Román, A.N.; Reis, J. Mediterranean diet: The role of long-chain $\omega$-3 fatty acids in fish; polyphenols in fruits, vegetables, cereals, coffee, tea, cacao and wine; probiotics and vitamins in prevention of stroke, age-related cognitive decline, and Alzheimer disease. Rev. Neurol. 2019, 175, 724-741. [CrossRef]

286. Lewandowska, U.; Szewczyk, K.; Hrabec, E.; Janecka, A.; Gorlach, S. Overview of Metabolism and Bioavailability Enhancement of Polyphenols. J. Agric. Food Chem. 2013, 61, 12183-12199. [CrossRef]

287. D'Souza, S.; Addepalli, V. Preventive measures in oral cancer: An overview. Biomed. Pharmacother. 2018, 107, 72-80. [CrossRef]

288. De Nicolò, S.; Tarani, L.; Ceccanti, M.; Maldini, M.; Natella, F.; Vania, A.; Chaldakov, G.N.; Fiore, M. Effects of olive polyphenols administration on nerve growth factor and brain-derived neurotrophic factor in the mouse brain. Nutrion 2013, 29, 681-687. [CrossRef]

289. Leri, M.; Scuto, M.; Ontario, M.L.; Calabrese, V.; Calabrese, E.J.; Bucciantini, M.; Stefani, M. Healthy Effects of Plant Polyphenols: Molecular Mechanisms. Int. J. Mol. Sci. 2020, 21, 1250. [CrossRef] [PubMed]

290. Gorzynik-Debicka, M.; Przychodzen, P.; Cappello, F.; Kuban-Jankowska, A.; Marino Gammazza, A.; Knap, N.; Wozniak, M.; Gorska-Ponikowska, M. Potential Health Benefits of Olive Oil and Plant Polyphenols. Int. J. Mol. Sci. 2018, 19, 686. [CrossRef] [PubMed]

291. Petrella, C.; Farioli-Vecchioli, S.; Cisale, G.Y.; Strimpakos, G.; Borg, J.J.; Ceccanti, M.; Fiore, M.; Monteleone, G.; Nisticò, R. A Healthy Gut for a Healthy Brain: Preclinical, Clinical and Regulatory Aspects. Curr. Neuropharmacol. 2021, 19, 610-628. [CrossRef] [PubMed]

292. Azam, S.; Hadi, N.; Khan, N.; Hadi, S. Prooxidant property of green tea polyphenols epicatechin and epigallocatechin-3-gallate: Implications for anticancer properties. Toxicol. Vitr. 2004, 18, 555-561. [CrossRef] [PubMed]

293. Narotzki, B.; Reznick, A.Z.; Aizenbud, D.; Levy, Y. Green tea: A promising natural product in oral health. Arch. Oral Biol. 2012, 57, 429-435. [CrossRef] [PubMed]

294. Kraft, T.E.; Parisotto, D.; Schempp, C.; Efferth, T. Fighting Cancer with Red Wine? Molecular Mechanisms of Resveratrol. Crit. Rev. Food Sci. Nutr. 2009, 49, 782-799. [CrossRef] [PubMed]

295. Bianchini, F.; Vainio, H. Wine and resveratrol: Mechanisms of cancer prevention? Eur. J. Cancer Prev. 2003, 12, 417-425. [CrossRef] [PubMed]

296. Arranz, S.; Chiva-Blanch, G.; Valderas-Martínez, P.; Remon, A.M.; Raventós, R.M.L.; Estruch, R. Wine, Beer, Alcohol and Polyphenols on Cardiovascular Disease and Cancer. Nutrients 2012, 4, 759-781. [CrossRef] 